\title{
Mobility Trends before and after the Pandemic Outbreak: Analyzing the Metropolitan Area of Barcelona through the Lens of Equality and Sustainability
}

\author{
Lucía Mejía-Dorantes $^{1, *(\mathbb{D}}$, Lídia Montero ${ }^{2} \mathbb{C}$ and Jaume Barceló ${ }^{2}$ \\ 1 Independent Consultant, 76185 Karlsruhe, Germany \\ 2 Department of Statistics and Operations Research, Campus Nord, Universitat Politècnica de \\ Catalunya (UPC), 08034 Barcelona, Spain; lidia.montero@upc.edu (L.M.); jaume.barcelo@upc.edu (J.B.) \\ * Correspondence: mejia-dorantes@web.de
}

Citation: Mejía-Dorantes, L.; Montero, L.; Barceló, J. Mobility Trends before and after the Pandemic Outbreak: Analyzing the

Metropolitan Area of Barcelona through the Lens of Equality and Sustainability. Sustainability 2021, 13, 7908. https://doi.org/10.3390/ su13147908

Academic Editor: Luigi Dell'Olio

Received: 31 May 2021

Accepted: 7 July 2021

Published: 15 July 2021

Publisher's Note: MDPI stays neutral with regard to jurisdictional claims in published maps and institutional affiliations.

\begin{abstract}
The spatial arrangement of a metropolis is of utmost importance to carry out daily activities, which are constrained by space and time. Accessibility is not only shaped by the spatial and temporal dimension, but it is also defined by individual characteristics, such as gender, impairments, or socioeconomic characteristics of the citizens living or commuting in this area. This study analyzes mobility trends and patterns in the metropolitan area of Barcelona before and after the COVID-19 pandemic outbreak, with special emphasis on gender and equality. The study draws on multiple sources of information; however, two main datasets are analyzed: two traditional travel surveys from the transport metropolitan area of Barcelona and two coming from smartphone data. The results show that gender plays a relevant role when analyzing mobility patterns, as already highlighted in other studies, but, after the pandemic outbreak, some population groups were more likely to change their mobility patterns, for example, highly educated population groups and those with higher income. This study also highlights that e-activities may shape new mobility patterns and living conditions for some population segments, but some activities cannot be replaced by IT technologies. For all these reasons, city and transport planning should foster sustainable development policies, which will provide the maximum benefit for society.
\end{abstract}

Keywords: mobility patterns; gender; equality; COVID-19 pandemic; big data; surveys

\section{Introduction}

Life dynamics of human societies are driven by activities whose realization requires the movement of people and goods, since their spatial and temporal distribution makes movement necessary to have timely access to places where activities are located. Transportation is the means necessary to access services, carry out different activities, enjoy the city, and in general terms, exercise our rights as citizens [1]. Transportation is shaped by constraints such as the distance between locations, the time when the locations must be reached, the topography of the geographic region, and the topology of the network spanning it. As explained by Rodrigue [2], transportation has the specific purpose of fulfilling a demand for mobility to move people and goods to the required locations. Transport, therefore, is the tool that makes accessibility possible, and as Rodrigue describes [2], its demand is namely a derived demand in most of the relevant journeys, leaving aside marginal trips for other purposes.

Accessibility to the realization of activities is thus at the core of the process, and mobility must then ensure the realization of accessibility, where citizens and goods must reach destinations to satisfy needs and have access to places where activities happen. Apart from the spatial dimension, individual characteristics shape citizens' decisions regarding access to places. These decisions are determined by different lifestyles [3] and socioeconomic and gender issues [4]. 
The connectivity and its sequel in accessibility is influenced by the urban form, that is the spatial arrangement of cities, and the urban spatial structure, the set of relationships arising out of the urban form and related spatial interactions of people and freight that depend on the land-use factors that generate and attract movements of passengers and freight between origins and destinations. Thus, achieving the target of sustainability in urban mobility concerns not only the technology but also the conditions determining the needs for accessibility to the realization of activities, and the former implies the needs of the different users of the transportation system physically ensuring the accessibility. Hence, a key question is whether or not the system offers equal levels of accessibility to transport to the different population groups. Different factors, such as gender, ethnicity, race, religion, sexuality, mental/physical ability, and economic class play an important role in accessibility $[5,6]$.

Although many times neglected, gender has played a major role in mobility and how we experience the city, as different studies worldwide show [7-9]. Moreover, in the last years, technology and the emergence of new mobility services have also shaped and transformed mobility patterns, especially for some population groups [10,11]. Moreover, the pandemic outbreak has posed great challenges to society, triggering important changes in living and mobility patterns that are necessary to understand. The changes brought about by the pandemic worldwide have been addressed through different perspectives [12-15]. Indeed, transport and city planning need to address all these issues through a comprehensive perspective to assure a sustainable and inclusive recovery.

The aims of this study are threefold: first, to study the role that gender has played in the mobility of the Metropolitan Area of Barcelona; and second, to analyze the changes triggered by the COVID-19 pandemic in the light of sustainability and equality. Third, we discuss different factors that shape mobility, such as teleworking conditions, urban development, and dwelling locations to understand new trends. For that sake, we make use of different primary and secondary datasets and multiple information sources.

This paper is divided into five sections and organized as follows: After the introduction, the second section describes the case study, the methodological approach, and the datasets. The following section presents the results, and the fourth section presents the discussion. Finally, Section 5 contains the conclusions and discusses the main findings and policy implications of this study.

\subsection{Background}

City and transport planning are not gender neutral. Indeed, transport systems are a very powerful tool to exercise our right to the city [16], because, as described above, they support the physical connectivity of the territory and the possibility of materializing the physical mobility necessary to realize the activities that substantiate the condition of citizens. In 1999, the World Bank already observed that with current transportation systems still being strongly men oriented, women were more likely to be deprived of access to transport [17].

Transport and city planning fail to take gender differences into account: cities have been designed according to a traditional vision of people going from home to their job and backwards. However, a wide variety of examples worldwide show how the daily travel patterns differ among gender: Men have longer travel distances and more direct travel patterns than women. Women carry out many different activities, and many of the trips are related to the mobility of care: they often drop children off at schools or daycare, go shopping, accompany family members to medical services (or other activities), and take care of many household needs. For all these reasons, women have more complicated transport patterns, characterized by shorter and chained trips, with longer travel times, as many different studies observe [18]. Moreover, women rely more on public transport, whereas men use more private transportation.

These differences are relevant in different societies [4-9,19]. As shown by Eurostat [20], in Europe, the differences per gender regarding the participation in household and family 
care are notably relevant; therefore, the daily patterns differ. The European Institute on Gender Equality (EIGE) [21] also stresses that the disproportionate amount of time that women spend on care and unpaid work directly impacts employment opportunities and other activities, which reinforces gender segregation. All these factors contribute to shaping gendered mobility patterns [22].

\subsection{Cities and Migration Impacts}

The migration trend from rural to urban areas has always existed; however, urban growth has accelerated from the second half of the 20th century up to the point that in the year 2008, humanity crossed the threshold of having over $50 \%$ of the world population living in cities - a growing trend that is forecasted to surpass 70\% in 2050 [23]. These urban sprawl phenomena have generally occurred in an unplanned, anarchic way due to the combined results of various factors: the relative affluence drifting from rural to city populations, changes in lifestyles and, in particular, advances in personal mobility in the form of individual motorized mobility. This last factor implies a separation between dwelling and working areas, which is made possible by the development of transportation systems, which in turn are accompanied by the well-known consequences that we call traffic congestion. In this respect, the LivingRAIL project [24] highlighted that public transport and rail investments were focused on main metropolitan areas in Europe, whereas there was a lack of investment in reliable rail transport services in the low to medium cities, obliging people in low-populated areas to mainly rely on private transport modes; hence, for the sake of sustainability, the connectivity of these areas should be enforced [25]. The former affects especially female travel patterns, which are characterized by trip chaining.

The current situation, of course, has had strong impacts on energy consumption and emissions (currently, around $75 \%$ of greenhouse gases of anthropogenic origin are produced by cities [26]) and, consequently, on the quality of life. This phenomenon is having a relevant impact on spatial reorganization and, therefore, on the configuration of transport systems. This is a consequence of the mutual reciprocity between space and transport. Space configures transport just as transport shapes geography [27].

Furthermore, during the last years, major cities such as Barcelona experienced a rise in dwelling costs due to insufficient urban planning, along with the pressure from tourism and unregulated sharing platforms [28]. It made many local residents (especially mediumand low-income people) move to fringe areas increasing their commuting time and costs. This issue is more relevant for women as they have more household responsibilities and suffer from the gender gap.

This unaffordability of living in cities, not only for low but also for medium classes, is highlighted by Fahra as UN Special Rapporteur (2020) [29]. This issue, along with the decline in quality of life and the rise of each time stronger sustainability conscience, seems to have prompted the reverse migration from cities to rural areas, especially in young, well-educated people, who in teleworking could find demand-responsive and shared transportation systems as the support to that decision, as shown in Figure 1. This trend seems to have increased as a consequence of the situation created by the COVID19 pandemic, as different reports worldwide show (see for example [30-33]). The main question is whether this trend will continue after the pandemic and will become one of the factors configuring future societies and their mobility patterns, depending on technological, social factors, and gender issues [34]. 


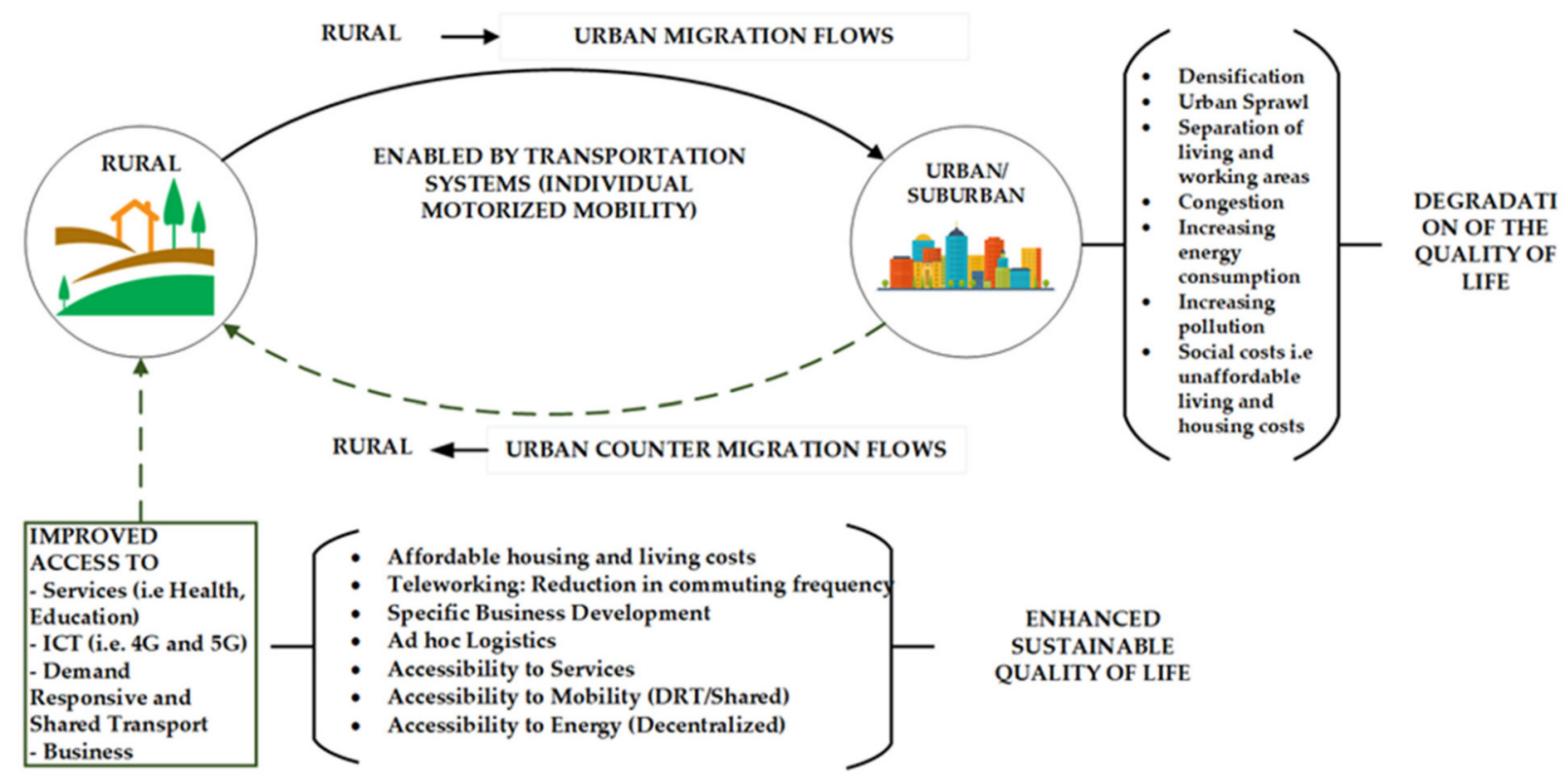

Figure 1. Urban-rural migration flows impacts.

\subsection{Consequences of the COVID-19 Pandemic}

The EIGE (2021) [35] observes that the COVID-19 has led to the largest drop in working hours in the EU-27 since 2006, greater than the financial crisis. In fact, the pandemic is also emerging unresolved issues and increasing social differences. Caregivers and frontline workers are not able to telework. During the worst pandemic waves, they kept commuting with more barriers than before (lower frequencies, higher risks). Gender segregation in employment is leading to different levels of exposure to COVID-19 for women and men. To mention some professions, in 2018 in Europe, women made up to $86 \%$ of personal care workers in health services, $93 \%$ of child care workers and teachers' aides, $95 \%$ of domestic cleaners and helpers, and $82 \%$ of cashiers in supermarkets [36]. Frontline workers have longer commuting trips and worse working conditions. Many of them lack sufficient health insurance or social security, and in many cases, they depend on the goodwill of employers, as they may be irregular workers. According to [37], women's jobs are 1.8 times more vulnerable to this crisis than men's jobs, and although women make up 39 percent of global employment, they account for 54 percent of overall job losses. This situation is expelling women from the labor market, reducing previous achievements, and affecting women's well-being.

\section{Materials and Methods}

\subsection{The Case Study of Barcelona Metropolitan Area}

The Metropolitan Area of Barcelona (AMB) has a territory of about $636 \mathrm{~km}^{2}$, and it comprises 36 municipalities, with more than 3.2 million inhabitants. Moreover, the AMB accounts for only $2 \%$ of the total Catalonian territory, but in it live almost $43 \%$ of the Catalonian population [38]. It is a unique cultural, economic, and social pole; the AMB concentrates half of the Gross Domestic Product (GDP) of Catalonia [38]. It has a dense public transport network, and, especially in the inner part, the street density is high, with many schools and other public services scattered across the city, which facilitates walking and cycling trips.

In 2016, the annual average household expenditure in Catalonia was 31 thousand euros [39]. Figure 2 shows the professional education per residential zones in the AMB. The traffic analysis zones used are the TAZ-EMO, which were defined in the Commuters' Mobility survey in 2001 [40]. 


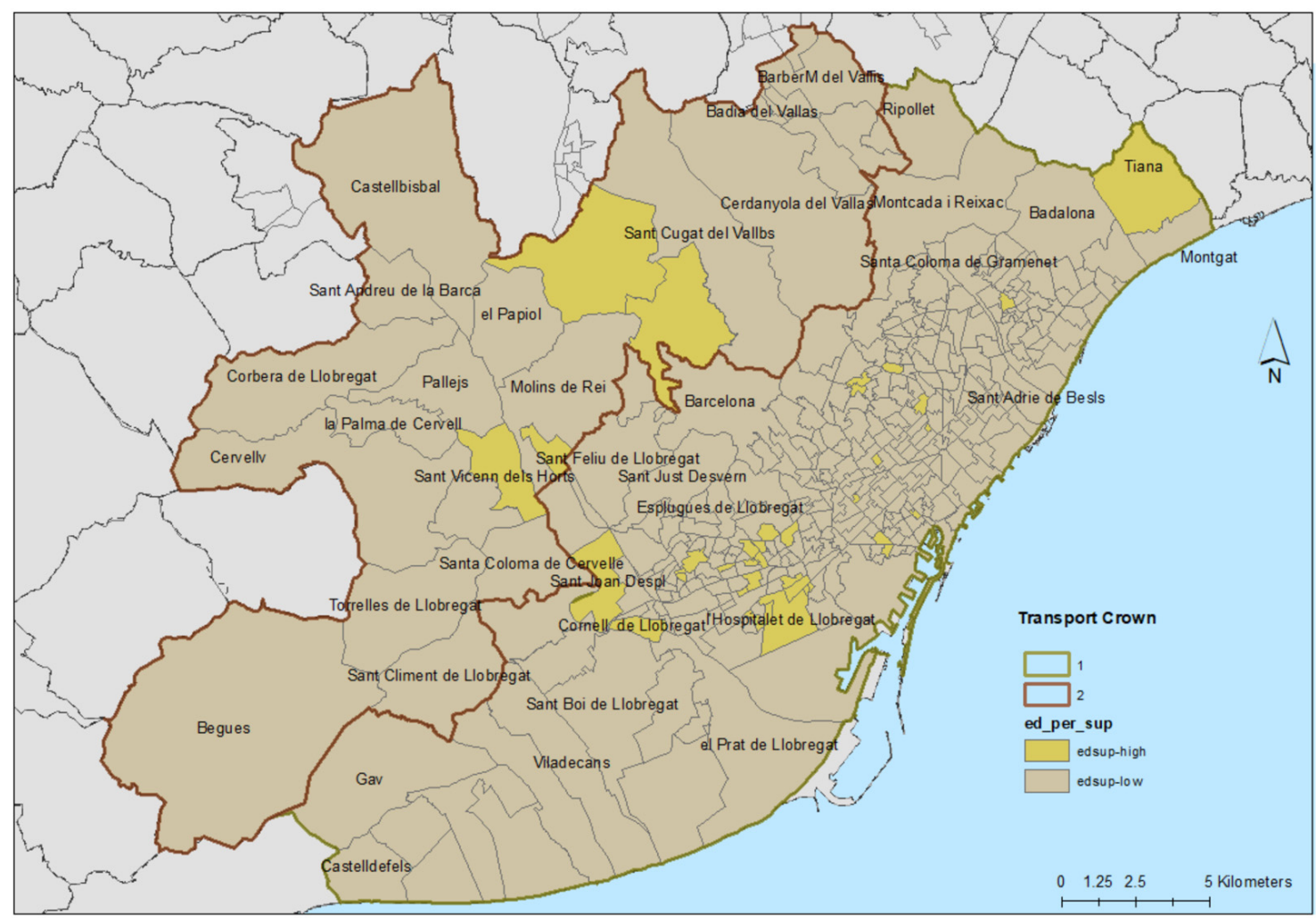

Figure 2. Barcelona Metropolitan Area according to the residential zones in the AMB and information regarding professional education (Cartographic information source [41] and TAZ-EMO [40]).

On the other hand, the study by Perez and Argomedo [42] states that in Barcelona in 2017, the gender gap reached $31 \%$ in the metropolitan area and $28 \%$ in the municipality.

According to [43], approximately $25 \%$ of the daily mobility in the Municipality of Barcelona is a local trip, accessible by walking. As in other studies, gender determines modal choice and length of a trip. To solve constrained schedules, men increase motorization rates, whereas women increase proximity trips. This situation is possible thanks to the fact that educational and other public services are well dispersed within the municipality.

Authors in [42] observe that women travel more for personal issues than for work. A large share of the personal issues trips has to do with unavoidable mobility, which means doctor appointments, escorting, or care mobility. These unavoidable trips increase between women living in lower-income areas.

On the other hand, authors in [18] observe that in Barcelona, women are more mobile in the first and second metropolitan ring, which are less dense areas, thanks to private mobility in car-dependent developments. Given the gender gap in Catalonia, it seemed to provide benefits although this issue confronted the sustainability principle [44].

\subsubsection{Migration as a Result of Technological Changes}

An official report from the Census Department of the Municipality of Barcelona [44] draws its attention to the socioeconomic aspects of the phenomenon. The report identifies changes in the emigration and immigration flows, the typology of the selected emigration destinations, and the socioeconomic profiles of the emigrants. The collected data show that:

- Barcelona is smoothly losing population, breaking the growing trend in recent years.

- Emigration is higher than immigration.

- Emigrants from Barcelona choose as destination small municipalities outside the Metropolitan Region.

- Emigration flows are originated in city zones with medium-high and high incomes. 
- The destination municipalities are namely of fewer than 5000 inhabitants, and the emigration is homogeneous from all districts.

Concerning the emigrants' profiles, they are predominantly capable of teleworking; in general terms, emigrant people and their families depend on efficient internet coverage as an essential connectivity tool. The selection of the destinations indicates that they mostly rely on individual motorized mobility and not on public transport. At a first glance, qualitatively, these results look consistent with the result provided by the survey conducted by Eurofound [34] concerning teleworking and profiles of teleworkers. However, more detailed information is needed.

\subsubsection{The COVID-19 Impact}

Spain experienced one of the most severe lockdowns in Europe (Figure 3). Many people worked from home, while others had to reduce their working hours or lost their jobs. Children were in homeschooling, and outdoor activities were severely restricted. Only frontline workers were allowed to commute, and indispensable care activities were carried out. It is worth noting that in Spain, women make up to $66 \%$ of health workers, $84 \%$ nurses, and $84 \%$ of elderly care workers [45]. In Catalonia, women make up to $22.9 \%$ of people employed in education, healthcare, and social work, compared to $6.8 \%$ of men [46]. Between the end of April 2020 and until June 21st, the lockdown restrictions were eased according to the incidence per province. During this period, many services reopened, such as schools and daily care services.

\section{Covid-19 weekly cases per 100,000 inhabitants in Spain and Catalonia}

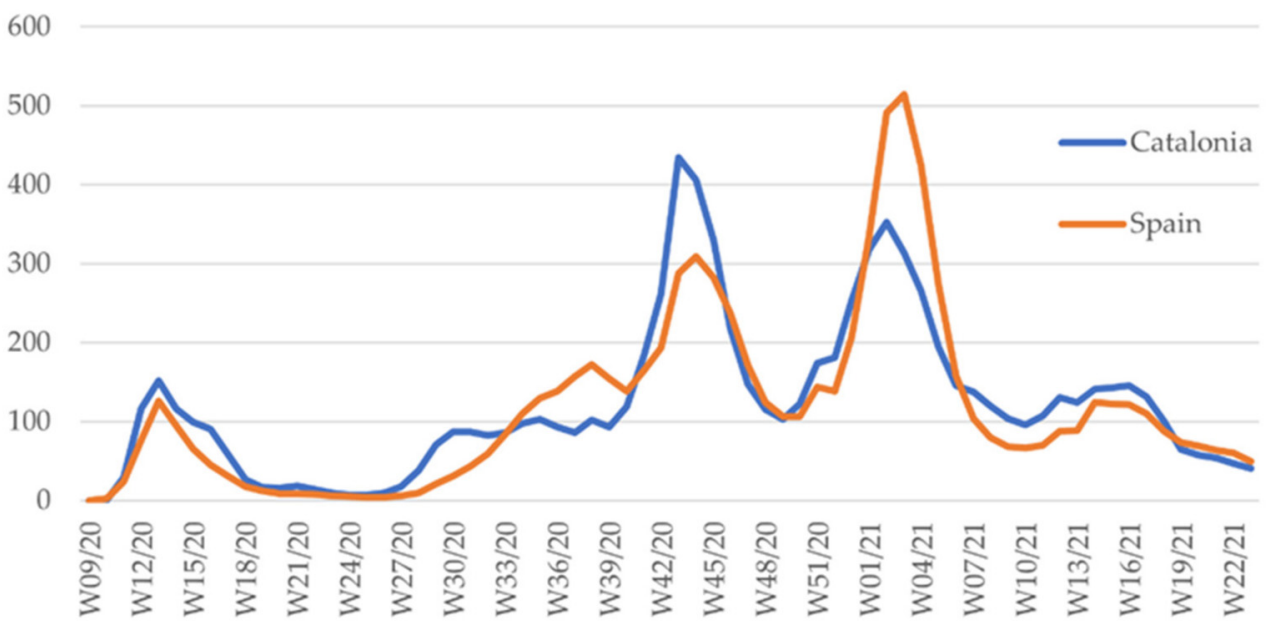

Figure 3. Weekly COVID-19 confirmed cases over 100,000 inhabitants in Catalonia and Spain (Original data source: https:/ / www.idescat.cat/dades/covid19, accessed on: 21 June 2021).

The pandemic outbreak changed commuting patterns. In Spain, in 2019, only $4.8 \%$ were usually working from home (half of the week or more), and $3.5 \%$ were occasionally working from home [47]. Catalonia had in 2019 a similar average to the rest of Spain. Spain lags behind the rest of EU countries in working from home: according to Eurostat in 2019, $5.4 \%$ of employed persons usually worked from home [48]. Recent surveys show that nowadays only $14.7 \%$ of employees telework occasionally or regularly in Spain, and in Barcelona, this share increases to $17.2 \%$ [49]. However, people that telework tend to be high-skilled workers with better wages and contract conditions.

Interestingly, according to the report by [50], rail mobility in Barcelona (metro, suburban rail, and tramway) decreased during the first lockdown, especially in those areas with 
higher income, whereas in areas with lower income, the decrease in rail mobility was not so drastic.

\subsection{Methodological Approach}

There are different types of datasets that may be used to analyze mobility. For example, statistics of different levels, land-use information, information of the transport infrastructure use and services, and especially transport mobility sources. Travel surveys have been used to obtain rich information on mobility patterns, and nowadays, big data provides us with more alternatives to analyze mobility [51]. See for example the study on Germany [52].

To carry out this study, we made use of two different databases both involving the Barcelona Metropolitan Area (Figure 4). The first set comes from the Working Day Mobility Survey, EMEF, 2018 and 2019 [53] to analyze the situation before the pandemic outbreak. The second is the Origin to Destination (OD) matrices from cell phones on the average working day of 2019 and June 2020.

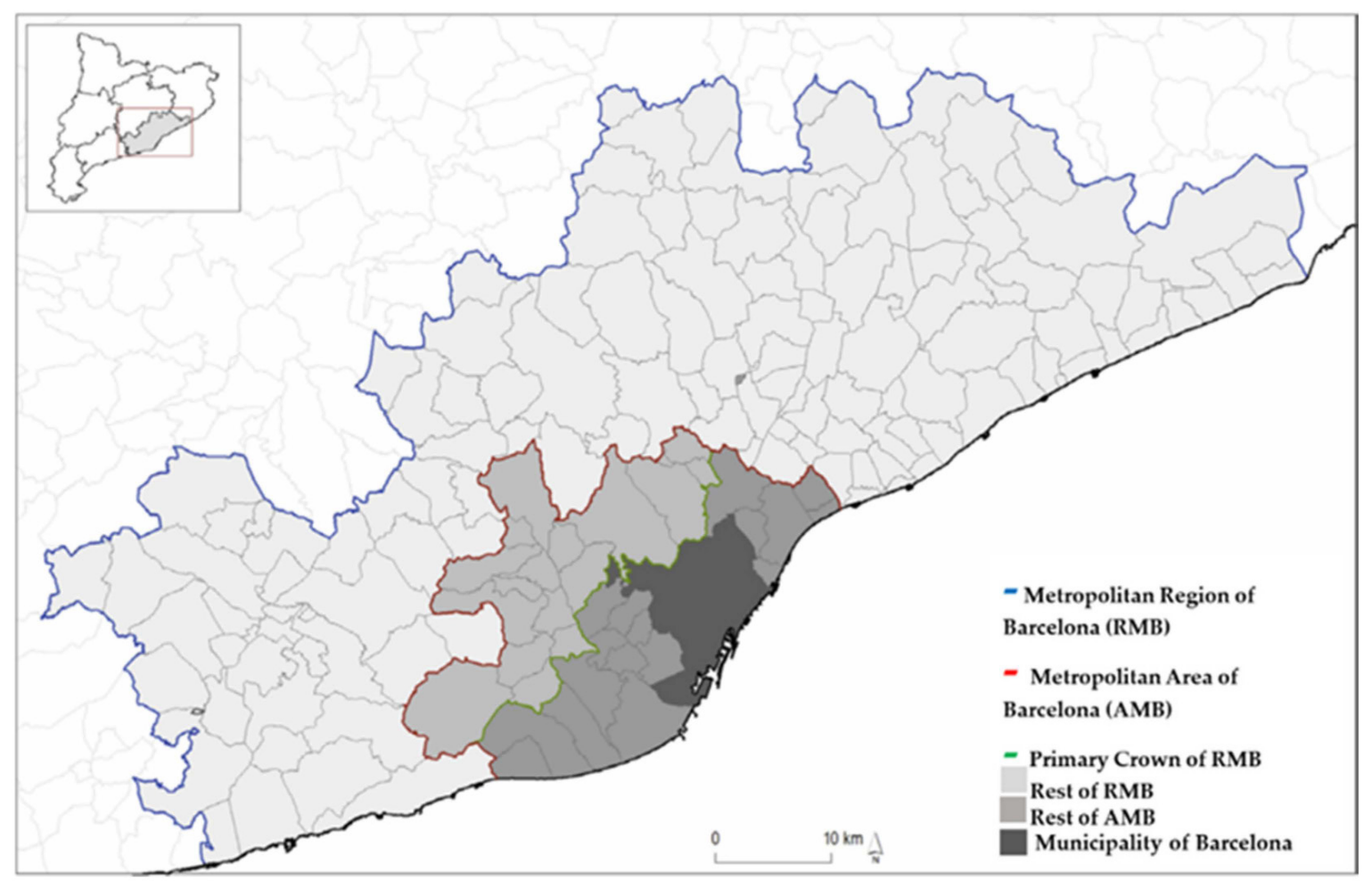

Figure 4. Metropolitan Area of Barcelona. Subarea definition: Primary Crown, AMB and RMB.

The TAZ-EMO zoning system is a geographical division of the study area, which is standard to transport authorities and urban planners, and it is used as the reference by the NOMMON data source [40]. Each survey has its opportunities and shortcomings as shown in Table 1:

- OD matrices produced by NOMMON (2019-2020): They provide an expanded number of trips segmented by daily periods, gender, age group (in four groups defined as 16-29, 30-44, 45-64, and >64), purpose on origin and purpose on destination (H-home, W-work, NF-casual, and O-others) and TAZ-EMO origin, TAZ-EMO destination and TAZ-EMO residential in the Metropolitan Region of Barcelona (AMB). Neither trip travel times, nor lengths are included. The TAZ-EMO Transportation Analysis Zones (TAZ-EMO) are defined by transport authorities. The study area (AMB) is split into 372 TAZ-EMO and the Broad the Metropolitan Region of Barcelona (RMB) into 582 TAZ-EMO, but only 14 according to NOMMON macrozones are included in the 
RMB subarea out of AMB. NOMMON is a technological company that elaborates OD matrices from smartphone data of Orange cellphone customers. The NOMMON 2020 data collection was extracted in June 2020 (see Figure 3, week 23-27).

- EMEF 2018-2019: These are traditional mobility surveys that analyze the mobility of residents in a working day in the broad Metropolitan Region of Barcelona (RMB) for citizens aged 16 and over. The spatial granularity is at the municipality level, but Barcelona is divided into districts (10), leading to a total of 296 macrozones, only 45 of them in the AMB study area. The approach given in the analysis of this mobility is twofold: firstly, characterization of mobility in general made by the resident population; and secondly, analysis of the territorial relations that are established based on the origins and destinations of the trips. The information collected for each journey refers to the origin and destination macrozones, purpose, mode, travel start time and duration (min), vehicle use, parking use, etc. A second part of the survey provides information on the assessment of general elements related to public transport.

Table 1. EMEF (Working Day Mobility Survey 2018-2019, IERMB) and NOMMON (cell phone data 2019-2020): Advantages and shortcomings.

\begin{tabular}{|c|c|c|}
\hline Type of Dataset & Travel Survey & Cell Phone Data \\
\hline Monetary and time costs & Higher & Lower \\
\hline Personal information & $\begin{array}{l}\text { Detailed personal, educational level, } \\
\text { socioeconomic. }\end{array}$ & $\begin{array}{l}\text { Gender, age (in groups } 16-29,30-44, \\
45-64,65+\text { ) }\end{array}$ \\
\hline Sample size & Sample which needs to be expanded & $\begin{array}{c}\text { approx. } 40 \% \text { trips, expanded to } \\
\text { population }\end{array}$ \\
\hline Empty cells & $80 \%$ & $20 \%$ \\
\hline Travel choices & Yes & No \\
\hline Opinion & Yes & No \\
\hline Travel purpose & Yes (detailed) & Yes; but broader \\
\hline Number of trips & Yes & No \\
\hline Trip Travel time & Yes & No \\
\hline Trips time slot & Yes & Yes \\
\hline
\end{tabular}

More information about mobility data from cell phones may be found in [54]. Through this methodology, it is possible to infer travel choices through cell phone data (limited).

Data orchestration is needed to combine EMEF and NOMMON mobility sources since transport analysis zones are not the same for the AMB (45 zones according to EMEF and 372 TAZ-EMO for NOMMON). A second drawback to face relies on the categories defined as trip purposes, being very detailed in EMEF data and limited for NOMMON source. A compromise to align both sources has been set to define home-based purposes as homebased to work (HBW), home-based not frequent (HBC), and home-based frequent (HBO). Non-home-based purposes are matched in both datasets to define non-home-based-home (NHBH), non-home-based to work (NHBW), and non-home-based others (NHBO). Trip characteristics referring to the period of the day $(7-10,13-15,17-20$, and other) are also available in both datasets.

The transportation mode and journey travel time (precision is low) are also available in the EMEF data. Journey time has been imputed into the NOMMON data using a transportation planning model for the study area [55]. The transportation mode in the EMEF data has been grouped into active (walking), micromobility, public transport, private transport, and others.

Characteristics of trip makers are defined for both datasets as gender (2 categories), age-group (16-29, 30-44, 45-64 and 65, and more), and residential zone based on TAZEMEF. A rough indicator referred to income per capita can be imputed to both sources based on TAZ-EMO values provided by available land-use and urban planning data. 
The EMEF datasets contain additional characteristics such as education level, activity group (student, active, unemployed, retired, and nonactive), and car availability among others. On the other hand, the NOMMON data information is described in Table 2.

Table 2. NOMMON 2019 and 2020 combined database: variable description of OD trips.

\begin{tabular}{|c|c|}
\hline Variable Name & Description \\
\hline mun.res & Residential TAZ-EMO \\
\hline mun.ori & Trip TAZ-EMO origin \\
\hline mun.des & Trip TAZ-EMO destination \\
\hline franja & Daily period: $7-10,13-15,17-20$ and others \\
\hline PURMOD & $\begin{array}{l}\text { Trip purpose (aggregated). Either HBW (Home-Based to Work), HBC (Home-based casual), HBO } \\
\text { (Home-based others), NHBH (Return to home), NHBW (Non-Home-Based to Work) and NHBO } \\
\text { (Non-Home-Based Others) }\end{array}$ \\
\hline gender & Gender (Male/Female) \\
\hline gedat & Age group factor (4 levels, $16-29,30-44,45-64$ and 65 and more) \\
\hline corori & Origin Crown (3 levels, $\mathrm{AMB}, \mathrm{RMB}$ and others) \\
\hline cordes & Destination Crown (3 levels, AMB, RMB and others) \\
\hline corres & Residential Crown (3 levels, AMB, RMB and others) \\
\hline nbtrips & $\begin{array}{l}\text { Expansion coefficient of OD trips according to the residential area by the gender and age-group } \\
\text { segment they belong to. }\end{array}$ \\
\hline year & Either 2019 or 2020 \\
\hline r_rm_pond_pob & Average income per capita for the residential zone of commuters \\
\hline ed_per_pri & Average primary education percentage for the residential zone of commuters \\
\hline ed_per_sec & Average secondary education percentage for the residential zone of commuters \\
\hline ed_per_sup & Average high education percentage for the residential zone of commuters \\
\hline taz.emef & Macrozone of residential area for commuters \\
\hline munnom & Residential municipality name for commuters \\
\hline f.pcrent & Income per capita for residential zone of commuters in 5 levels \\
\hline f.edupri & $\begin{array}{c}\text { Binary factor containing low-high percentage of primary educated residents for residential area } \\
\text { commuters }\end{array}$ \\
\hline f. edusec & $\begin{array}{c}\text { Binary factor containing low-high percentage of secondary educated residents for residential area } \\
\text { trip makers }\end{array}$ \\
\hline f. edusup & $\begin{array}{c}\text { Binary factor containing low-high percentage of highly educated residents for residential area } \\
\text { commuters }\end{array}$ \\
\hline taz.emef.x & Origin macrozone of the trips \\
\hline taz.emef.y & Destination macrozone of the trips \\
\hline munnom.x & Origin TAZ-EMO code of the trips \\
\hline munnom.y & Destination TAZ-EMO code of the trips \\
\hline ODcor & OD Crown of the trips \\
\hline nn & $\begin{array}{c}\text { Number of inhabitants in the residential TAZ-EMO of commuters by gender and age-group segment } \\
\text { they belong to. }\end{array}$ \\
\hline triprate & $\begin{array}{c}\text { Number of inhabitants in the residential TAZ-EMO of commuters by gender and age-group segment } \\
\text { they belong to. }\end{array}$ \\
\hline
\end{tabular}

\section{Results}

A first comparative analysis involving 2018 and 2019 EMEF data sources was addressed using R [56] and RStudio [57], analyzing the number of trips performed by commuters. The results are shown in the following graphs. Figure 5 presents the descriptive gender-purpose-mode behavior bar-plots, where the $x$-axis groups together different transportation modes into: walking, micromobility, public transport, private transport, and others. On the other hand, Figure 6 describes the different transportation alternatives but per travel zone (crowns). The results show that walking is more common in females than males, and public transport shows a high proportion of women over any trip purpose. Interestingly, among any category of OD subarea (crowns), women show a greater use of sustainable trips (walking or public transport) than men as indicated in Figure 6. The micromobility incidence in men is higher. Similarly, men are more prone to use private transport, which is especially clear when male mobility is analyzed per mobility areas (crowns). The gender gap in mode use is consistent with findings described in [58]. 


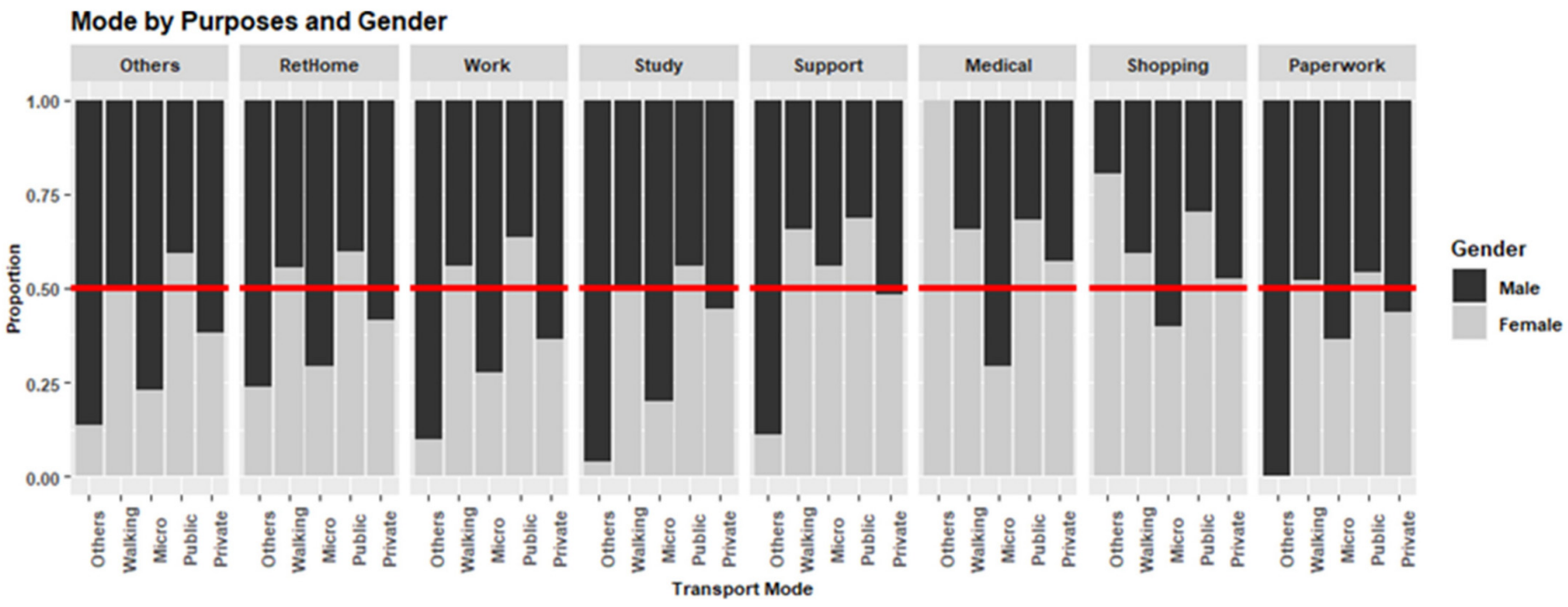

Figure 5. EMEF Survey. Mode-purpose by gender-relative proportions (Note: RetHome: come back home).

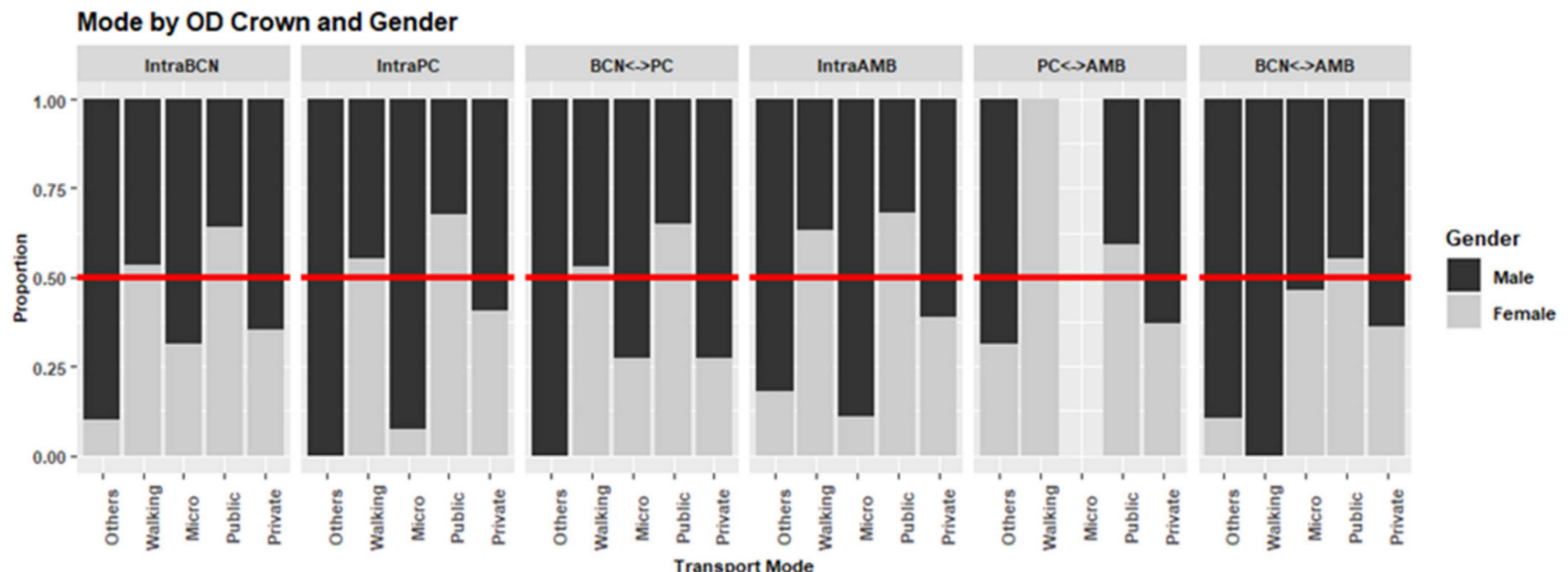

Figure 6. Exploratory analysis on EMEF data of gender behavior related to transportation mode and OD Crown journey categories: IntraBCN: trips within the municipality of Barcelona; IntraPC: Only primary crown trips (17 inner Municipalities) without the municipality of Barcelona; $B C N-P C$ : Municipality of Barcelona to/from other Municipalities in the primary crown; IntraAMB: all municipalities in the AMB out of the primary crown; PC-AMB: Municipalities out of Barcelona to the rest of the AMB; $B C N-A M B$ : Municipality of Barcelona from/to AMB municipalities out of the primary crown.

Moreover, a generalized linear model (GLM) of the total number of trips of the EMEF datasets using a negative binomial model was estimated and validated, since the Poisson model is not applicable due to the overdispersion of the outcome variable. Therefore, the model is specified as follows:

$$
\begin{gathered}
N b \_t r i p s \sim N B(\mu, k) \\
E\left(N b \_t r i p s \mid X\right)=\mu \\
\mu=\exp (\eta) \\
\eta=\beta_{0}+\sum_{i=1}^{n} \beta_{i} x_{i}
\end{gathered}
$$

The explanatory variables $\left(x_{i}\right)$ are gender, age group, activity, education level, purpose, mode and gender interactions with purpose, and mode. To cope with different TAZ-EMEF production/attraction trips according to the number of residents, a size offset term is included in the linear predictor. After controlling by gender, age group, activity, and 
education, a significant interaction appears between gender and trip purpose and gender and transportation mode. Similarly, Figures 5 and 6 had also suggested that there was a significant gender-purpose and gender-mode interaction; therefore, net-effect tests were undertaken. To analyze the results and to properly understand and interpret whether a term is worth with respect to all other terms in the model, it was conducted on the basis of the ANOVA statistical technique, which in this case is based on the analysis of deviance. These tests use the reference statistic distribution (Fisher test). The net-effect tests for a generalized linear model are implemented in car library in $\mathrm{R}$ through the Anova() method. Results are presented in Table 3. Trip rates by residents show significant gender-purpose and gender-mode interaction effects.

Table 3. EMEF survey data. Number of trips based on individual characteristics.

\begin{tabular}{ccccc}
\hline \multicolumn{5}{c}{ Deviance Test for Net-Effects and Interactions } \\
\hline Variable & Deviance & Degrees of Freedom & F Value & Pr $(>$ F) \\
\hline gender & 13 & 1 & 97,193 & 0.0018251 \\
age_group & 50 & 3 & 125,544 & $3.37 \times 10^{-05}$ \\
activity & 99 & 5 & 150,037 & $9.61 \times 10^{-12}$ \\
education & 257 & 5 & 390,317 & $<2.2 \times 10^{-16}$ \\
purpose & 305 & 7 & 331,174 & $<2.2 \times 10^{-16}$ \\
mode & 2584 & 4 & 491,378 & $<2.2 \times 10^{-16}$ \\
gender:purpose & 32 & 7 & 35,079 & $9.124 \times 10^{-4}$ \\
gender:mode & 122 & 4 & 231,661 & $<2.2 \times 10^{-16}$ \\
Residuals & 41,770 & 31,768 & & \\
\hline
\end{tabular}

These results prove gendered mobility patterns and gendered model choices. They are in line with other authors' findings [18]. As previously indicated, mode data and descriptive characteristics are available in EMEF data, but they are unavailable in NOMMON data.

The next step of analysis is to understand what happened after the pandemic outbreak and analyze changes in mobility patterns. For that, we compare travel behavior and the total number of trips between 2019 and 2020, immediately after the end of the strict lockdown period in Spain (June 2020, see Figure 3, weeks 23-27) using the NOMMON data.

The graphical representation of the OD trips in the Metropolitan Area of Barcelona according to gender and year (2019-2020) can be seen in Figures 7 and 8. In both figures, trips in the inner part of Barcelona diminished between 2019 and 2020. Moreover, trips from/to El Prat de Llobregat decreased. The BCN airport is located in this municipality.

It is worth noting that in Figures 7 and 8, only trips from different TAZ zones are shown. To compare the graphs, a fixed scale among years and gender was used. Top figures refer to female 2019 and 2020 number of trips, respectively. Bottom figures refer to male 2019 and 2020 trips (blue) number of trips, respectively. Filling colors in 5 tones are linked to average per-capita income [59]. For clarity purposes, trips below 400 are not shown. There was a reduction of trips carried out in the same zone (TAZ) for female commuters in 2019 to 2020 of $1.50 \%$ whereas, for male commuters, the reduction is of about $1.36 \%$, which is the trips more likely to be carried out by sustainable modes. 


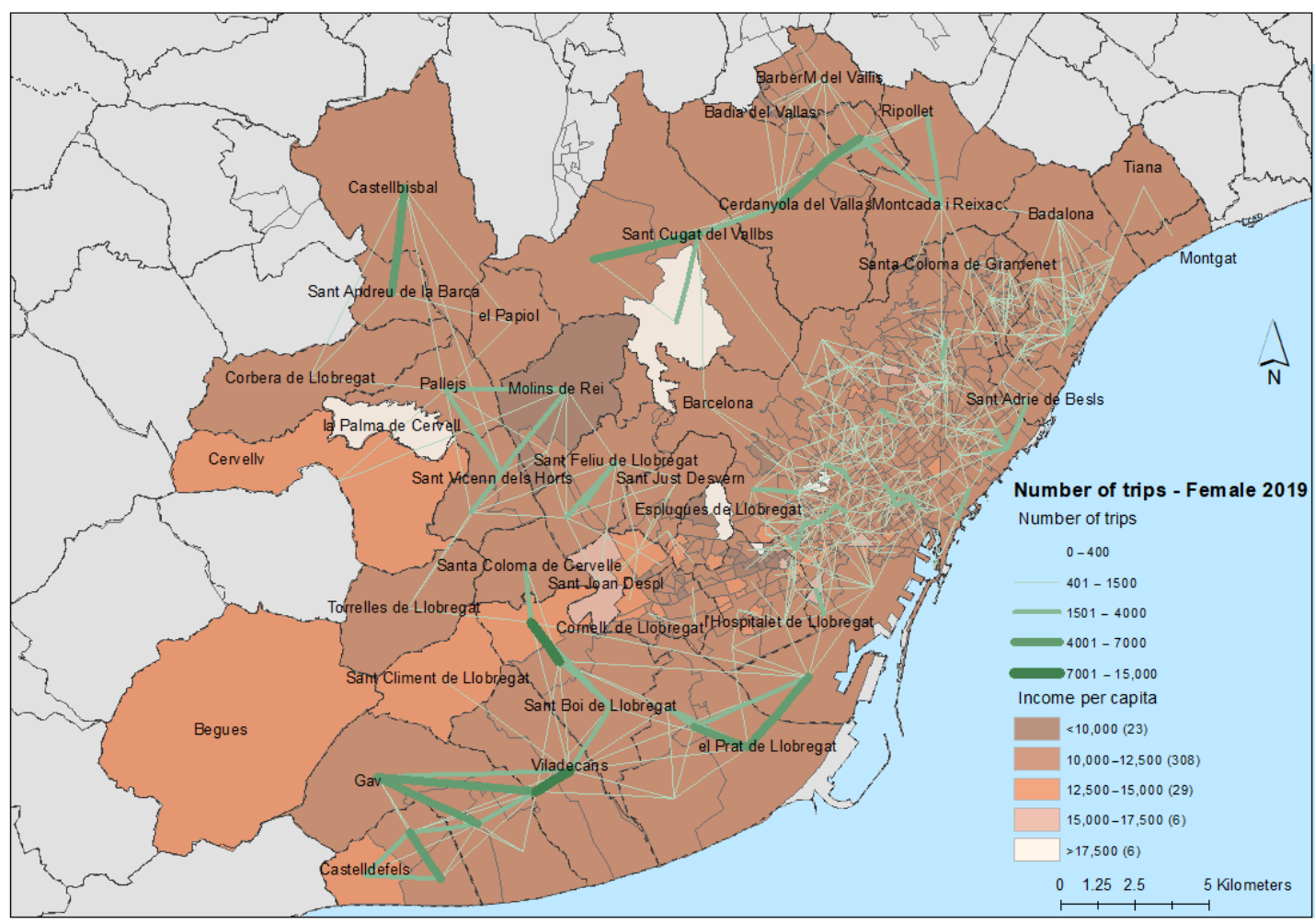

(a)

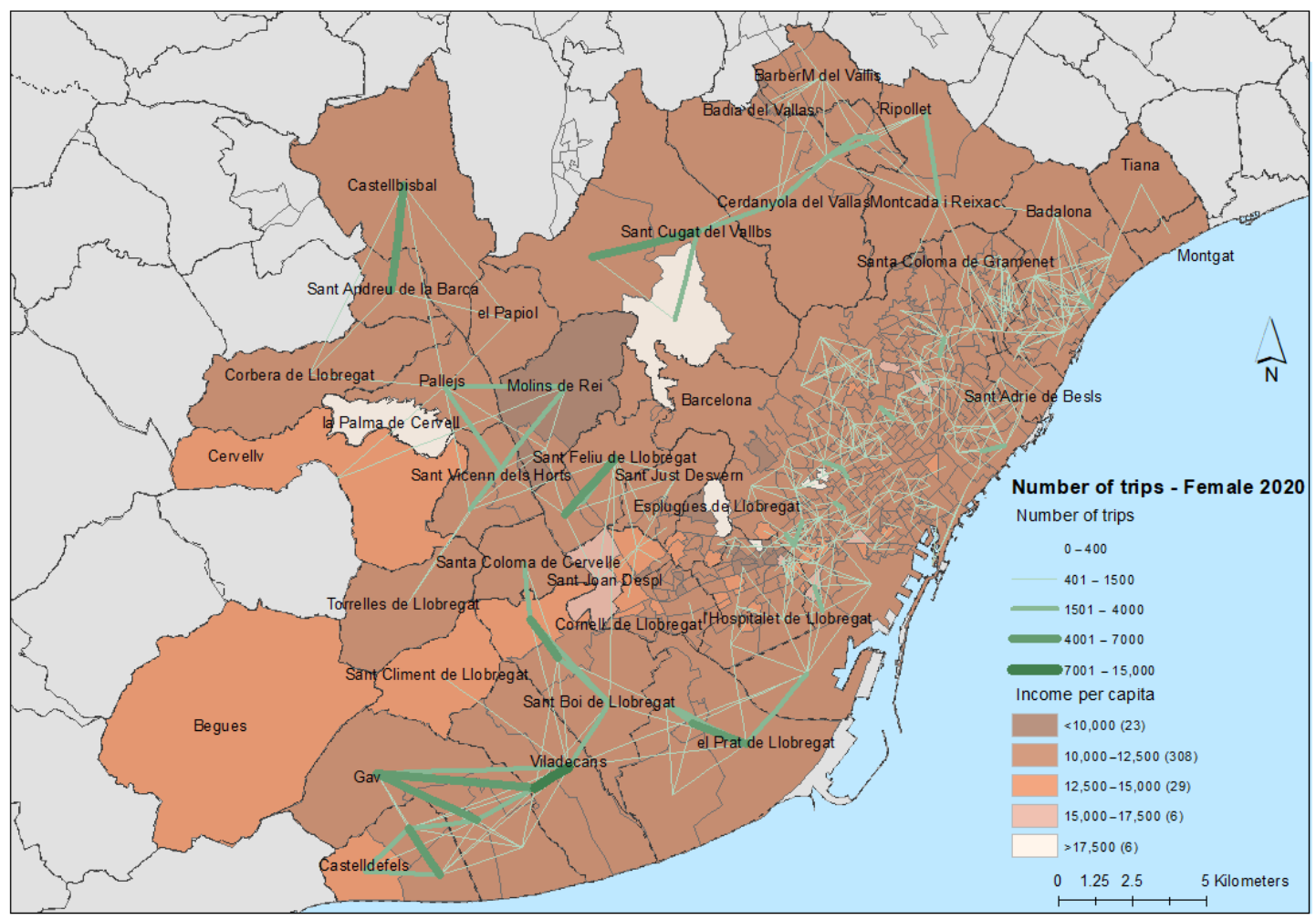

(b)

Figure 7. OD female trips in the Metropolitan Area of Barcelona in (a) 2019 and (b) 2020. 


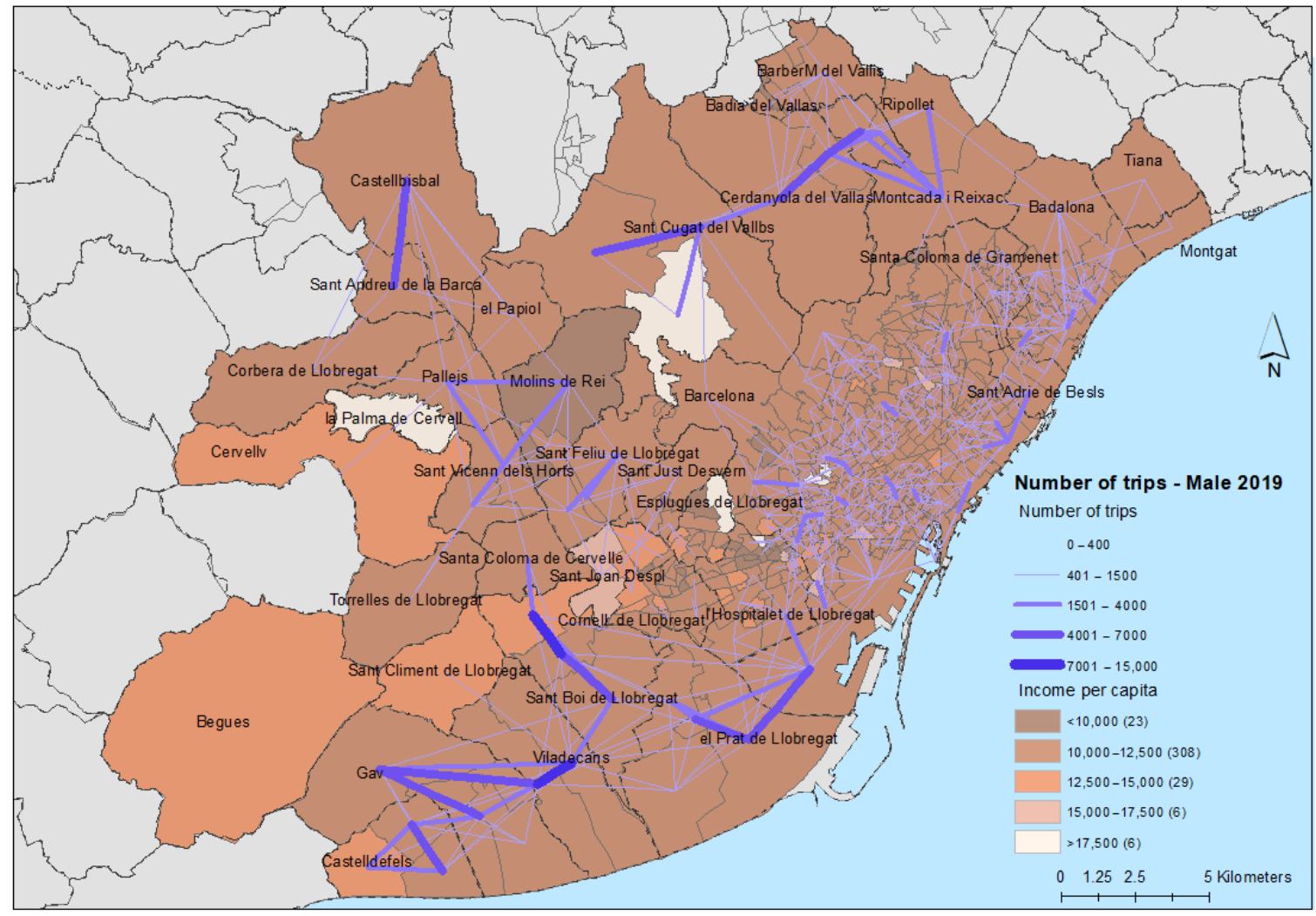

(a)

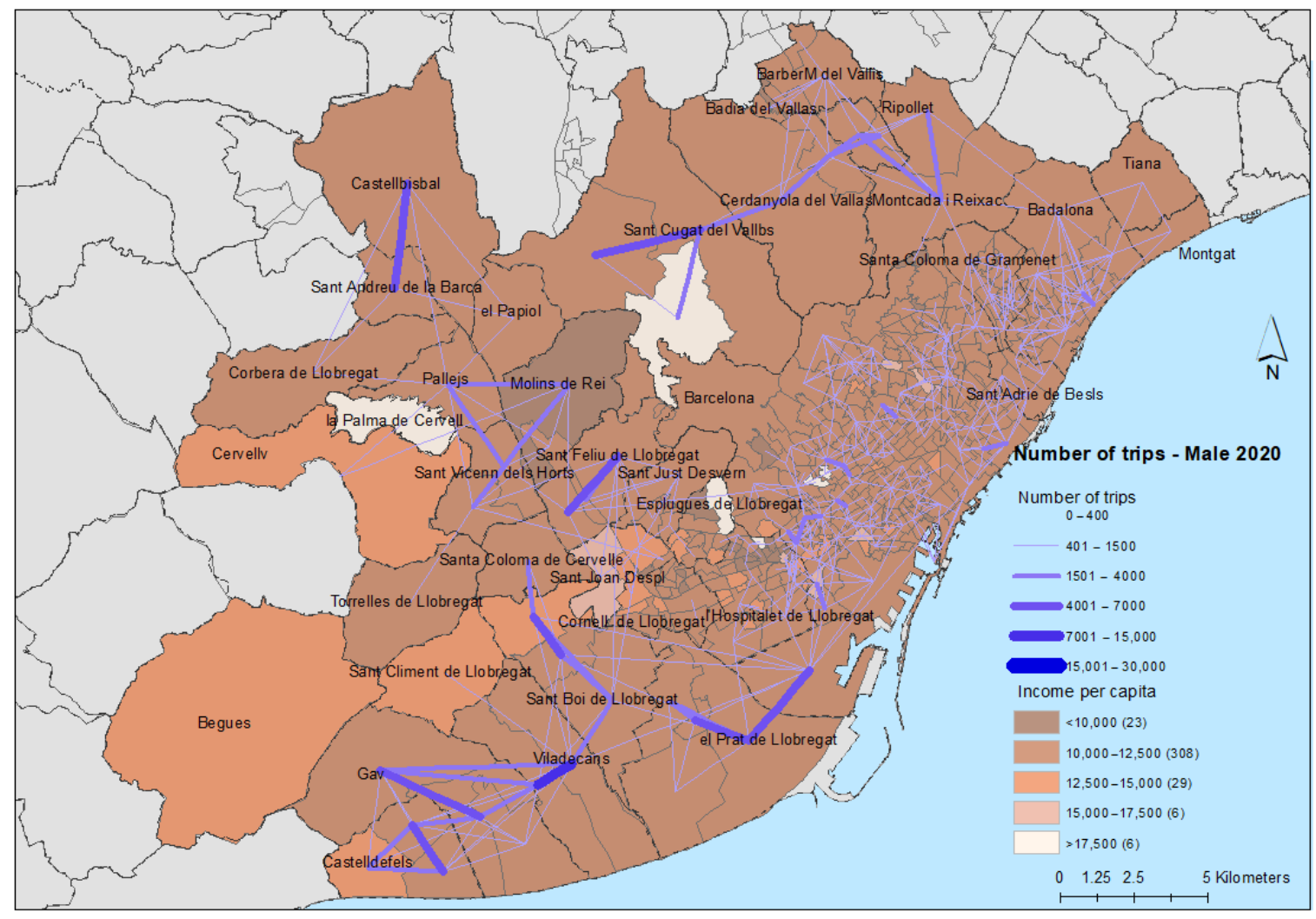

(b)

Figure 8. OD male trips in the Metropolitan Area of Barcelona in (a) 2019 and (b) 2020. 
In comparison to the above, if the dataset is analyzed by subareas (crowns), an overall $30 \%$ reduction in the total number of trips is found between average 2019 and June 2020, more remarkable on trips with origin and/or destination in Barcelona city (Table 4).

Table 4. Smartphone-based data. Daily trips on a working day 2019-2020.

\begin{tabular}{cccc}
\hline Metropolitan Subarea & $\mathbf{2 0 1 9}$ & $\mathbf{2 0 2 0}$ & $\begin{array}{c}\mathbf{2 0 2 0} \\
\text { Decrement }\end{array}$ \\
\hline Barcelona-City (intra) & $3,879,090$ & $3,005,290$ & $22.5 \%$ \\
Primary Crown (intra) & $2,040,975$ & $1,916,593$ & $6.1 \%$ \\
Barcelona- Primary Crown & $1,206,404$ & 910,357 & $24.5 \%$ \\
Second Crown-RMB (intra) & 490,621 & 473,821 & $3.4 \%$ \\
Primary $\leftrightarrow$ Second Crowns & 231,517 & 190,350 & $17.8 \%$ \\
Barcelona $\leftrightarrow$ Second Crowns & 177,169 & 116,660 & $34.2 \%$ \\
\hline
\end{tabular}

Figure 9 shows the number of trips per purpose between 2019 and 2020. It shows in general terms a significant reduction affecting all trip purposes but home-based nonfrequent trips (HBC). This point is interesting, and a possible assumption is that after the strict lockdown, many residents started carrying out outdoor activities, which may be registered as HBC trips. Further analyses, using for example a qualitative approach, may be necessary to understand this change.

\section{Purpose by year and gender}

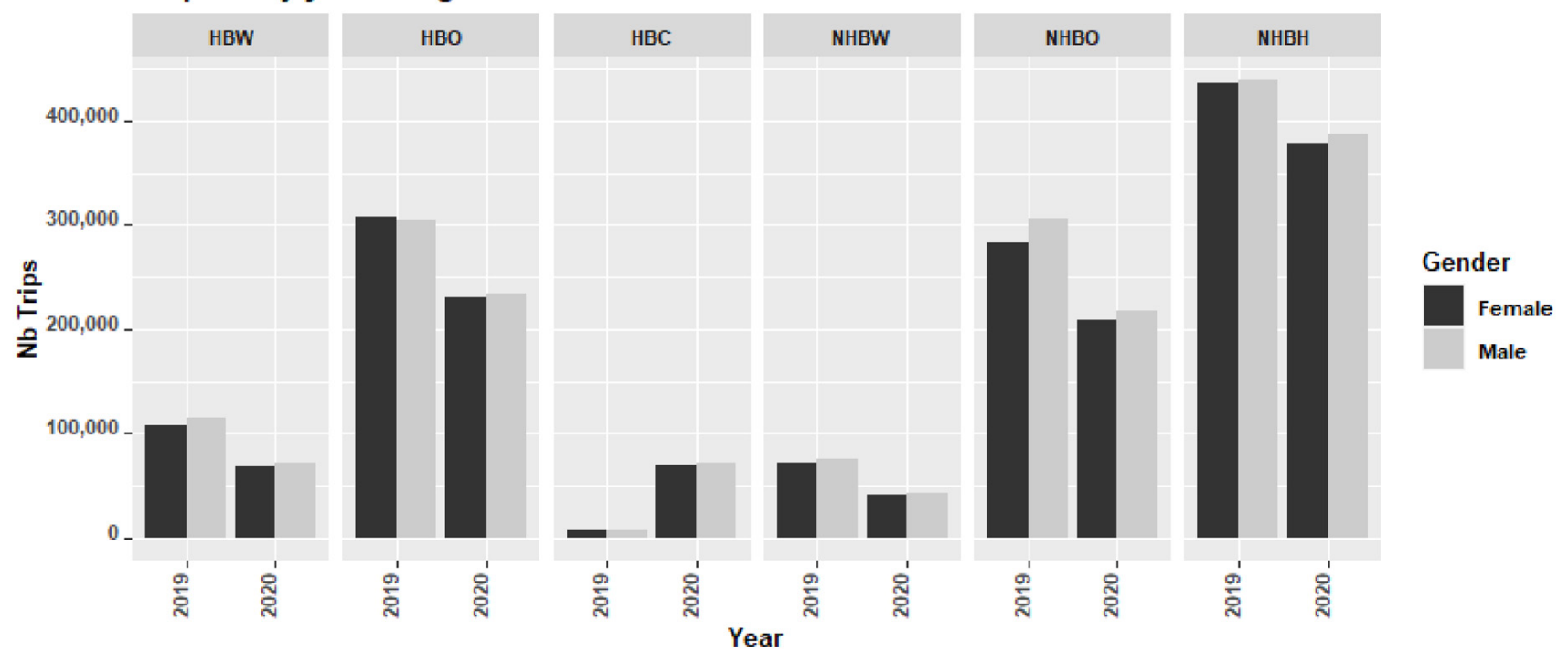

Figure 9. Nommon smartphone-based data. Daily trips by purpose, gender, and year. The number of trips (Nb Trips) is analyzed according to different trip purposes: home-based to work (HBW); home-based frequent trip (HBO); homebased not frequent trip (HBC); non-home-based to work (NHBW) and non-home-based others (NHBO); non-home-based home $(\mathrm{NHBH})$.

As shown in the previous Figure 9, work-related trips show a dramatic decrease from 2019 to 2020. Figure 10 shows the number of trips per subarea according to the Metropolitan subareas (HBW and NHBW purposes). It is worth noting the remarkable decrease in interior trips in Barcelona city and those with Barcelona as origin or destination. This information coincides with the trend found in Table 4. 


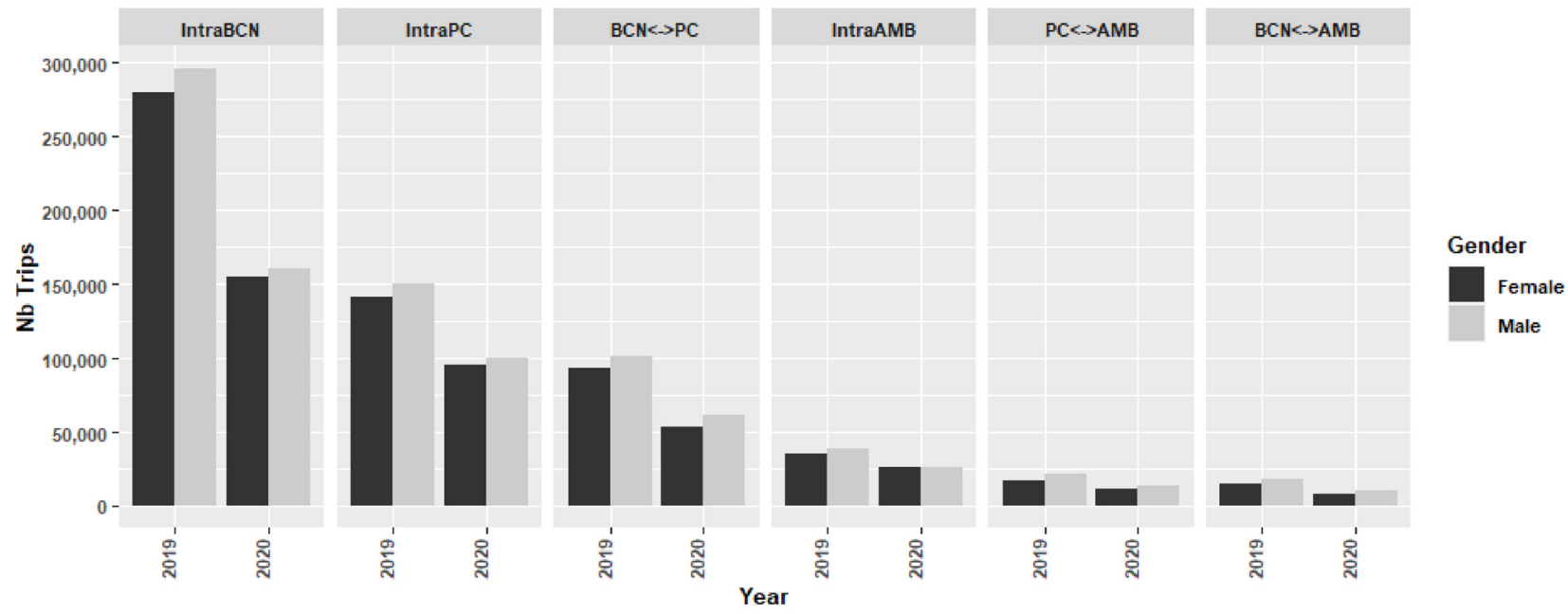

Figure 10. Smartphone-based data. Daily work-related trips by year and AMB subarea. Number of trips per categories: IntraBCN: within the municipality of Barcelona; IntraPC: Only primary crown trips (18 inner Municipalities) without the municipality of Barcelona; $B C N-P C$ : Municipality of Barcelona to/from other Municipalities in the primary crown; IntraAMB: trips in the region of $\mathrm{BCN}$ out of the $\mathrm{PC} ; P C-A M B$ : primary crown to the region out of the $\mathrm{AMB} ; B C N-A M B$ : Barcelona out of the primary crown but in the AMB.

The information of income per capita has been imputed into NOMMON 2019-2020 trips by taking into account available income per capita of residential TAZ-EMO zones.

An exploratory analysis was carried out using the mobile phone data and considering the per capita rent information. The results are shown in Figure 11. They indicate that the total number of trips decreased from 2019 to 2020. However, they did not decrease homogeneously with respect to all socioeconomic categories: trips performed by lowincome groups tend to be similar between 2019 and 2020, whereas teleworking seems to be a privilege reserved for medium-high and high-income groups, usually living in residential areas showing a large high-educational-level percentage. The study is limited to internal AMB trips made by AMB residents. This hypothesis will be checked in the next stage of this study through another GLM model. A gender effect is suspected and has been analyzed in greater depth without being able to confirm any statistically significant effect of gender because we lack detailed individual information to understand the behavior.

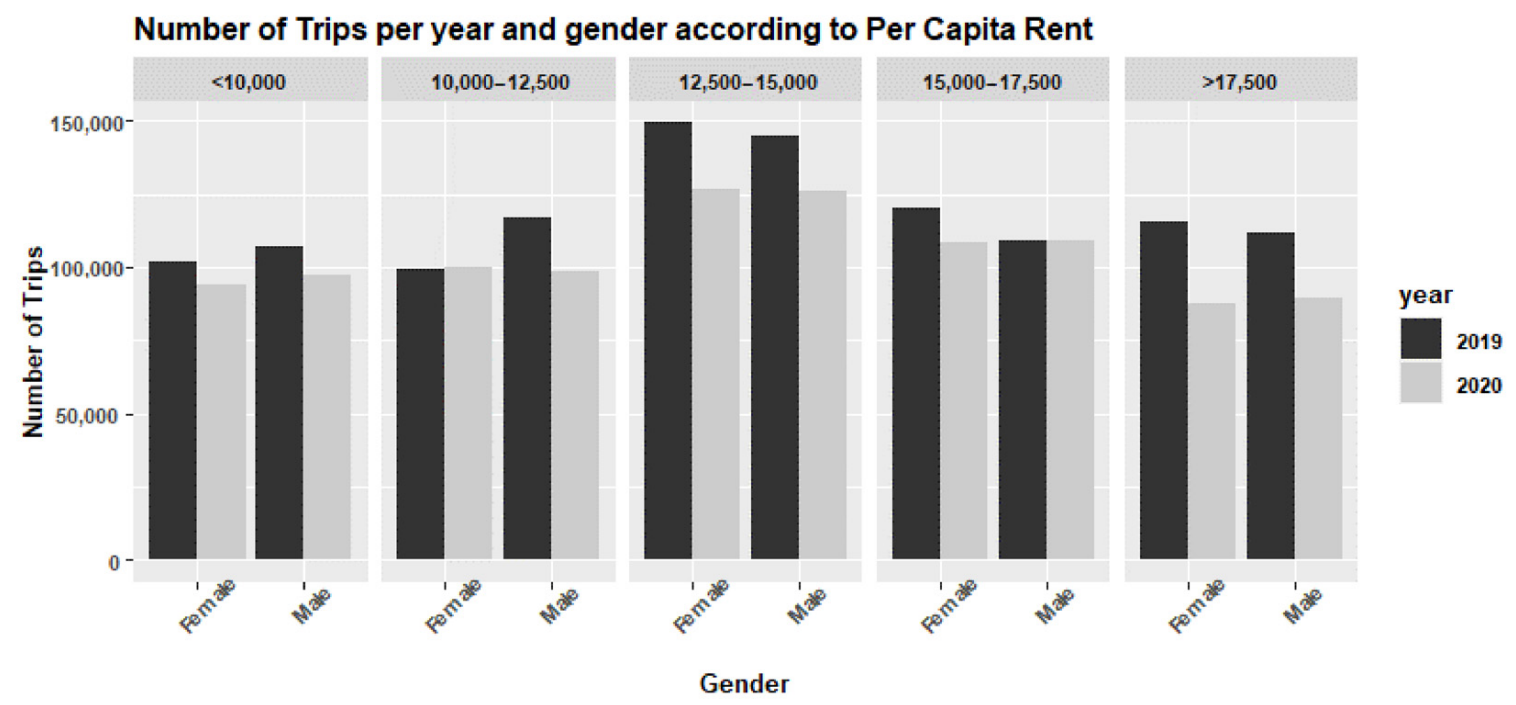

Figure 11. Smartphone-based data. Total daily trips according to income per capita and year. AMB residents only. 
The database structure of NOMMON data is shown in Table 2. It contains the total number of OD trips performed by gender, age group, origin, destination, residential TAZEMO, and day period according to NOMMON 2019 and 2020 datasets combined into the same data structure. It contains 4,967,146 registers accounting for 14,512,961 trips (2019 plus 2020 trips) only for the AMB area.

These datasets are not suited for directly applying a negative binomial model on the total number of trips at TAZ-EMO residential area, gender, and age-group level for yearbased comparison purposes. To model the number of trips properly, the total population by TAZ-EMO year, residential area, gender, and age group were included from official sources in such a way that an offset can be included in the generalized linear models; de facto, offset addition represents applying the proposed model to the total trip rate by year, gender, and age group in a residential area. This new aggregated dataset consists of 35,378 registers (AMB only) which is a more reasonable size to deal with using standard statistical methods in R/RStudio. The variables appearing in the aggregated dataset prepared for the generalized negative binomial models are detailed in Table 5.

Table 5. NOMMON 2019 and 2020 aggregated database: Total trips.

\begin{tabular}{|c|c|}
\hline Variable Name & Description \\
\hline $\begin{array}{l}\text { Triprate (target variable) } \\
\text { mun.res }\end{array}$ & $\begin{array}{c}\text { Number of trips per number of inhabitants in the residential TAZ-EMO of commuters } \\
\text { Residential TAZ-EMO }\end{array}$ \\
\hline PURMOD & $\begin{array}{l}\text { Trip purpose (aggregated). Either HBW (Home-Based to Work), HBC (Home-Based Casual), HBO } \\
\text { (Home-Based Others), NHBH (Return to Home), NHBW (Non-Home-Based to Work) and NHBO } \\
\text { (Non-Home-Based Others) }\end{array}$ \\
\hline gender & Gender (Male/Female) \\
\hline gedat & Age group factor (4 levels, $16-29,30-44,45-64$ and 65 and more) \\
\hline nbtrips & $\begin{array}{c}\text { Total number of trips by residents in mun.res in the age group and gender segment they } \\
\text { belong to. }\end{array}$ \\
\hline year & Either 2019, or 2020 \\
\hline r_rm_pond_pob & Average per capita rent for the residential zone of commuters \\
\hline ed_per_pri & Average primary education percentage for the residential zone of commuters \\
\hline ed_per_sec & Average secondary education percentage for the residential zone of commuters \\
\hline ed_per_sup & Average high education percentage for the residential zone of commuters \\
\hline munnom & Residential municipality name of commuters \\
\hline f.pcrent & Income per capita for residential zone of commuters in 5 levels \\
\hline f.edupri & $\begin{array}{c}\text { Binary factor containing low-high percentage of primary educated residents for residential area } \\
\text { commuters }\end{array}$ \\
\hline f. edusec & $\begin{array}{c}\text { Binary factor containing low-high percentage of secondary educated residents for residential area } \\
\text { commuters }\end{array}$ \\
\hline f. edusup & $\begin{array}{c}\text { Binary factor containing low-high percentage of highly educated residents for residential area } \\
\text { commuters }\end{array}$ \\
\hline nn & $\begin{array}{c}\text { Number of inhabitants in the residential TAZ-EMO of commuters by gender and age-group } \\
\text { segment they belong to }\end{array}$ \\
\hline
\end{tabular}

As in the previous dataset, negative binomial models from the GLM were carried out due to the aggregated typology of the datasets. They follow the similar specification as in Equations (1)-(4). Poisson models for the total number of trips were discarded since again they do not deal with overdispersion phenomena, whereas negative binomial models cope with the overdispersion present in the data. A zonal offset term is included in the linear predictor, and it has been defined according to gender and age group of the total population for each residential zone, making the model behave as modeling trip rates according to gender and age of the in the residential area for the different purposes.

The final model coefficients are shown in Table 6. It accounts for the year, gender (2 levels), purpose (6 levels), age group (4 levels), income group (5 levels), and interactions for year-income group and year-purpose, plus the zonal offset. It has 24 parameters; all net effects are significant at 95\% confidence level (see Table 7), and McFadden R2 is equal to 0.3 , which is a rather acceptable value for a GLM. 
Table 6. Negative binomial model for trip rate by gender and age group in residential area. Estimated model parameters.

\begin{tabular}{|c|c|}
\hline Estimates & Coefficients \\
\hline Gender Male & $0.095^{* * *}(0.008)$ \\
\hline PURMOD HBO & $0.984^{* * *}(0.021)$ \\
\hline PURMOD HBC & $-2.383^{* * *}(0.025)$ \\
\hline PURMOD NHBW & $-1.056^{* * *}(0.019)$ \\
\hline PURMOD NHBO & $0.141^{* * *}(0.019)$ \\
\hline PURMOD NHBH & $1.205^{* * *}(0.021)$ \\
\hline age.group 30-44 & $0.098^{* * *}(0.011)$ \\
\hline age.group 45-64 & $0.058^{* * *}(0.011)$ \\
\hline age.group 65-100 & $-0.320^{* * *}(0.012)$ \\
\hline Year 2020 & $-0.415^{* * *}(0.028)$ \\
\hline f.pcrent $10,000-12,500$ & $-0.020(0.017)$ \\
\hline f.pcrent $12,500-15,000$ & $0.030 *(0.017)$ \\
\hline f.pcrent $15,000-17,500$ & $0.046^{* *}(0.021)$ \\
\hline f.pcrent $>17,500$ & $-0.117^{* * *}(0.019)$ \\
\hline year2020:f.pcrent $10,000-12,500$ & $0.015(0.025)$ \\
\hline year2020:f.pcrent $12,500-15,000$ & $-0.037(0.024)$ \\
\hline year2020:f.pcrent 15,000-17,500 & $-0.084^{* * *}(0.030)$ \\
\hline year2020:f.pcrent > 17,500 & $-0.045(0.028)$ \\
\hline year2020: PURMOD HBO & $0.244^{* * *}(0.031)$ \\
\hline year2020: PURMOD HBC & $2.453 * * *(0.033)$ \\
\hline year2020: PURMOD NHBW & $0.058^{* *}(0.028)$ \\
\hline year2020: PURMOD NHBO & $0.194^{* * *}(0.027)$ \\
\hline year2020: PURMOD NHBH & $0.279^{* * *}(0.030)$ \\
\hline Constant & $-2.399 * * *(0.021)$ \\
\hline Observations & 117,061 \\
\hline Log Likelihood & $-641,480.600$ \\
\hline Akaike Inf. Crit. & $1,283,009.000$ \\
\hline
\end{tabular}

Note: ${ }^{*} p<0.1 ;{ }^{* *} p<0.05 ;{ }^{* * *} p<0.01$.

Table 7. Negative binomial model for trip rate by gender and age group in residential area. Net-effects tests. All terms are significant. Note: PURMOD means trip purpose.

\begin{tabular}{ccccc}
\hline Variable & Sum Sq & $\begin{array}{c}\text { Degrees } \\
\text { of Freedom }\end{array}$ & F Value & $\operatorname{Pr}(>\mathbf{F})$ \\
\hline gender & 263 & 1 & 141,505 & $<2.2 \times 10^{-16 * * *}$ \\
\hline PURMOD & 74,653 & 5 & $8,036,593$ & $<2.2 \times 10^{-16 * * *}$ \\
\hline age.group & 2669 & 3 & 478,924 & $<2.2 \times 10^{-16 * * *}$ \\
\hline year & 305 & 1 & 164,306 & $<2.2 \times 10^{-16 * * *}$ \\
\hline f.pcrent & 304 & 4 & 40,855 & $<2.2 \times 10^{-16 * * *}$ \\
\hline year:f.pcrent & 30 & 4 & 4063 & $0.002696^{* *}$ \\
\hline year:PURMOD & 11,912 & 5 & $1,282,362$ & $<2.2 \times 10^{-16 * * *}$ \\
\hline Residuals & 217,434 & 117,037 & & \\
\hline$N$
\end{tabular}

Note: ${ }^{*} p<0.1 ;{ }^{* *} p<0.05 ;{ }^{* * *} p<0.01$. 
The model shows that the oldest population group is less likely to travel, in comparison to other groups. As expected, the year (2020) accounts for a mobility decrease. Again, as shown in Figure 9, in year 2020, the HBC estimate (home-based not frequent trip) is high and significant.

In 2020, higher-income groups decreased their mobility in comparison to the lowestincome group. This information is further developed in Figure 12. There, the graphical marginal effects of number of trips and the model interactions of income with respect of the year (year:f.pcrent) are displayed.

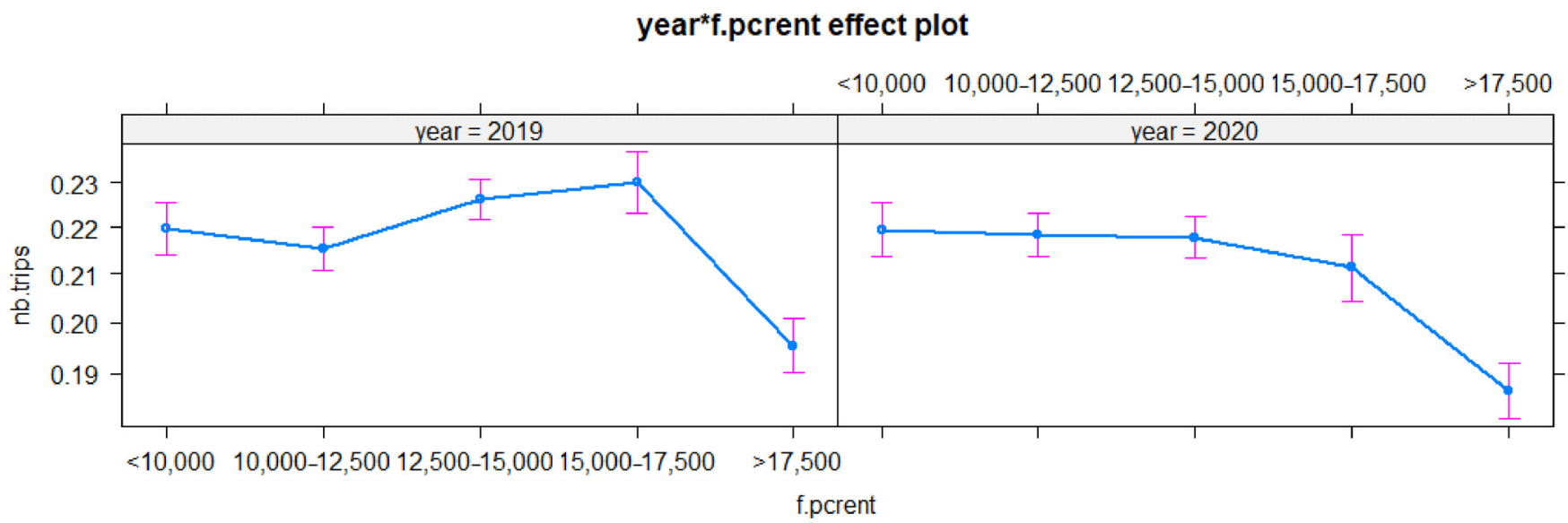

Figure 12. Negative binomial model for trip rate by gender and age group in residential area. Graphical behavior for year and per capita income level interactions.

As can be noticed in Figure 12, people in the highest income group (defined by the variable f.pcrent) commuted less in 2019 in comparison to other income groups already before the pandemic outbreak. In 2020, after the pandemic outbreak, people in the lowerincome groups, which in most cases are employed in frontline jobs, did not diminish their trip rate between 2019 and 2020. One can also observe that people with higher wages were the ones that diminished the most their number of trips between 2019 and 2020, in comparison to people with lower wages.

\section{Discussion}

The evolution of digital connectivity has prompted changes in work organization, whereas the technology adoption and the increase in activities that do not need a trip depend on: activities susceptible of being performed by IT-means, such as teleworking or online shopping. These activities are only possible if IT infrastructure exists and is able to support it; therefore, the accessibility of IT services becomes a key factor.

However, the analysis of how people move, the purposes, and the use of transport modes, shows that many activities strongly depend on socioeconomic and gender factors revealing that some essential activities (basic food supply services, manufacturing, lastmile deliveries, health care, etc.) require physical presence, which means that they are not susceptible of being realized virtually, and thus physical trips are unavoidable to realize them. How can we configure future societies, the cities, and their mobility, by splitting them into e-activities (namely e-shopping and teleworking) and non-e-activities, and their dynamics considering technological, socioeconomic factors, and gender issues?

Although migration to central and suburban areas has already happened before, IT services pose new alternatives to mobility. Unfortunately, with few exceptions, as indicated by [60] between countries, there is not yet enough data to quantitatively study the phenomenon and determine whether it is significant or not and whether the initial trends, already observed before the COVID-19 outbreak in some countries and metropolitan areas, due to the precedent economic crisis, which increased during COVID-19, will become permanent trends or only temporal phenomena with no substantial impact in the long 
term. However, this change has also been perceived by the media and newspapers [31,32]. While the first articles address the housing and living aspects, housing search changing trends has been identified by some portals. Here, the conditions required for e-activities, in terms of internet coverage, are of utmost importance as a key factor for this migration.

Unfortunately, neither in the emigration data from Barcelona [61] nor in the teleworking analysis of the Euroform survey [34], are gender issues explicitly addressed, although gender is one of the data collected; therefore, although these datasets show aspects that will likely affect sustainability, nothing can be inferred directly about gender issues. A positive impact will be the reduction in the number of trips since no daily commuting trips will be necessary. On the other hand, other activities will be carried out by using private vehicles for traveling and not public transport. Here, dwelling policies that meet sustainable development goals and population needs are of utmost importance. Finally, considering the profiles of the emigrants, for example, upper levels of income, with teleworking alternatives, indirectly some gender issues that are being discussed in this paper could also be applied here. Equality needs to be supported by care infrastructure. Mixed-land-use policies as in the inner part of Barcelona support sustainable transport alternatives.

The preferences by emigrants from Barcelona [44] shown after the COVID-19 pandemic and respondents to Eurofond survey [34] suggest that if additional conditions are met, with respect to access to services, online shopping, and shared mobility services, MaaS or DRT, then the trend will likely continue. More detailed research is necessary to understand this behavior.

\section{Conclusions}

Before the pandemic, the Barcelona case study showed that women were more likely to prefer sustainable modes, whereas micromobility alternatives were preferred by men. The micromobility alternative is not suitable for many typical female chained trips, such as shopping and escorting activities. Therefore, female citizens prefer public transport and walking, and as literature shows, in the outer rings of Barcelona, women also rely more on private transport. In this respect, cargo bikes may be an alternative to female mobility, in combination with other policies, such as private transport restrictions and traffic calming policies, along with a good infrastructure to foster active mobility. All these issues should be reinforced with a good level of public services, equally scattered, to facilitate active mobility.

On the other hand, the first reactions to the pandemic were related to how the virus equally impacted every single person, independently of their social, educational, and economic status. Nowadays, we know that this statement is inaccurate.

Current results comparing pre- and post-COVID-19 lockdown commuting patterns based on smartphone data indicate a significant effect depending on income level. Lowerincome groups present an increase in trip rates, while areas with higher education over the mean reduce trip rates (due to teleworking possibilities).

Wealthier people were more likely to reduce trips whereas poorer people could not reduce their trips, which increased the risk of exposure to COVID-19. Many of them were employed as frontline workers: basically, people who could not telework. In this respect, according to the statistics, women are more likely to work as frontline workers. Different studies observe that female workers have worse working conditions, and that the pandemic also exacerbated the differences among gender due to caring activities and nonremunerated homework.

The pandemic may increase the differences among economic classes. Wealthier people have increased teleworking share, many of them even moved (temporarily?) to their second home out of the city, which is good news for the sake of sustainability; however, some necessary trips may not be avoided, especially those related to the mobility of care. In this respect, wealthier people are more likely to reduce the number of trips in public transportation, preferring private transportation, which is again confronted with sustainable mobility. 
The pandemic could trigger major changes in the city: an increase in the use of IT technologies, rethinking unnecessary mobility and changing working schemes and services. All these issues should be thought in line with sustainability and equality policies.

Repopulating the low-density areas out of the metropolitan area of Barcelona may alleviate the exacerbated costs of living in the city, which might be an opportunity for people who telework and could reduce transportation, which positively impacts sustainability. However, those areas still need basic services and need to be reinforced with a mixed-landuse perspective; otherwise, many basic activities will still be carried out by traveling longer distances and, in many cases, making use of private transportation, which is in detriment of sustainability and would work in detriment to gender equality policies. On the other hand, policies that foster affordable housing, and due to characteristics of Barcelona, with a sustainable tourism perspective, could definitely contribute to rethinking the overall sustainability of the Metropolitan Area of Barcelona.

This study is, to a certain extent, hindered by the scarcity of data concerning gender issues. They are summarily addressed in conventional household and other surveys, until very recently added in a limited way. The EMEF is already a significant step toward this direction, but more datasets in this direction are needed, while those based on ICT technologies likely do not collect this information because it is not requested. It would be recommendable they consider the collection of these data to allow a deeper analysis.

This study leaves many doors open for further research. For example, a qualitative approach to understand the results in Figure 9 and Table 6 could be helpful to understand the increase between 2019 and 2020 of home-based nonfrequent trips (HBC). Moreover, Random Utility Models (RUM) could be a potential candidate for modeling trip purposes as a follow-up of the current research and a comparison of results through the RUM with a random sample using Logit and Generalized Extreme Value (GEV) models could be of interest. However, a higher level of granularity in data sources and additional variables as trip travel times/distances distributions would be necessary to facilitate this approach. Finally, a follow-up of migration trends is necessary to understand if this trend continues.

Author Contributions: Conceptualization, L.M.-D., L.M., and J.B.; Formal analysis, L.M. and L.M.-D.; Funding acquisition, L.M.; Investigation, L.M.-D. and J.B.; Methodology, L.M.-D., L.M., and J.B.; Validation, L.M.-D., L.M., and J.B.; Visualization, L.M.-D. and L.M.; Writing-review \& editing, L.M.-D., L.M. and J.B. All authors have read and agreed to the published version of the manuscript.

Funding: This research was partially funded by TRA2016-76914-C3-1-P Spanish R+D Programs and by Secretaria d'Universitats-i-Recerca-Generalitat de Catalunya- 2017-SGR-1749.

Institutional Review Board Statement: Not applicable.

Informed Consent Statement: Not applicable.

Data Availability Statement: The data that supports this study was used with permission of the Autoritat del Transport Metropolità (ATM) and Nommon for the current study, so they are not publicly available.

Acknowledgments: The datasets were kindly shared by the Autoritat del Transport Metropolità (ATM) and Nommon. Their contribution to our research is gratefully acknowledged.

Conflicts of Interest: The authors declare no conflict of interest.

\section{References}

1. Miralles-Guasch, C.; Frontera, À.C. Movilidad y Transporte. Opciones Políticas Para la Ciudad. Available online: https:/ / www.fundacionalternativas.org/laboratorio/documentos/documentos-de-trabajo/movilidad-y-transporte-opcionespoliticas-para-la-ciudad (accessed on 27 May 2021).

2. Rodrigue, J.P.; Comtois, C.; Slack, B. The Geography of Transport Systems; Taylor and Francis: London, UK, 2016; ISBN 9781317210108.

3. Lyons, G.; Mokhtarian, P.; Dijst, M.; Böcker, L. The dynamics of urban metabolism in the face of digitalization and changing lifestyles: Understanding and influencing our cities. Resour. Conserv. Recycl. 2018, 132, 246-257. [CrossRef]

4. Mejía-Dorantes, L.; Soto Villagrán, P. A review on the influence of barriers on gender equality to access the city: A synthesis approach of Mexico City and its Metropolitan Area. Cities 2020, 96. [CrossRef] 
5. Levy, C. Travel choice reframed: "Deep distribution" and gender in urban transport. Environ. Urban. 2013, 25, 47-63. [CrossRef]

6. Vacchelli, E.; Kofman, E. Towards an inclusive and gendered right to the city. Cities 2018, 76, 1-3. [CrossRef]

7. Hayden, D. What would a non-sexist city be like? Speculations on housing, urban design, and human work on JSTOR. Signs 1980, 5, 18. [CrossRef]

8. Jirón, P.; Carrasco, J.A.; Rebolledo, M. Observing gendered interdependent mobility barriers using an ethnographic and time use approach. Transp. Res. Part A Policy Pract. 2020, 140, 204-214. [CrossRef]

9. Joelsson, T.; Lindkvist Scholten, C. Integrating Gender into Transport Planning: From One to Many Tracks; Palgrave Macmillan: Cham, Germany, 2019; ISBN 9783030050429.

10. Abduljabbar, R.L.; Liyanage, S.; Dia, H. The role of micro-mobility in shaping sustainable cities: A systematic literature review. Transp. Res. Part D Transp. Environ. 2021, 92, 102734. [CrossRef]

11. Christoforou, Z.; Gioldasis, C.; de Bortoli, A.; Seidowsky, R. Who is using e-scooters and how? Evidence from Paris. Transp. Res. Part D Transp. Environ. 2021, 92, 102708. [CrossRef]

12. Christidis, P.; Christodoulou, A.; Navajas-Cawood, E.; Ciuffo, B. The post-pandemic recovery of transport activity: Emerging mobility patterns and repercussions on future evolution. Sustainability 2021, 13, 6359. [CrossRef]

13. Ceccato, R.; Rossi, R.; Gastaldi, M. Travel demand prediction during COVID-19 pandemic: Educational and working trips at the university of Padova. Sustainability 2021, 13, 6596. [CrossRef]

14. Politis, I.; Georgiadis, G.; Nikolaidou, A.; Kopsacheilis, A.; Fyrogenis, I.; Sdoukopoulos, A.; Verani, E.; Papadopoulos, E. Mapping travel behavior changes during the COVID-19 lock-down: A socioeconomic analysis in Greece. Eur. Transp. Res. Rev. 2021, 13, 1-19. [CrossRef]

15. Politis, I.; Georgiadis, G.; Papadopoulos, E.; Fyrogenis, I.; Nikolaidou, A.; Kopsacheilis, A.; Sdoukopoulos, A.; Verani, E. COVID19 lockdown measures and travel behavior: The case of Thessaloniki, Greece. Transp. Res. Interdiscip. Perspect. 2021, $10,100345$. [CrossRef]

16. Lefebvre, H.; Kofman, E.; Lebas, E. Writings on Cities; Wiley-Blackwell: Hoboken, NJ, USA, 1996; ISBN 978-0-631-19188-9.

17. Bamberger, M.; Lebo, J.; Gwilliam, K.; Gannon, C. Gender and Transport: A Rationale for Action; World Bank: Washington, DC, USA, 1999.

18. Cubells, J.; Marquet, O.; Miralles-Guasch, C. Gender and age differences in metropolitan car use. Recent gender gap trends in private transport. Sustainability 2020, 12, 7286. [CrossRef]

19. Cresswell, T. Gendering Mobility: Insights into the Construction of Spatial Concepts. In Gendered Mobilities; Uteng, T., Cresswell, T., Eds.; Routledge Taylor and Francis Group: London, UK, 2008; pp. 97-112.

20. Eurostat How do Women and Men Use Their Time-Statistics-Statistics Explained. Available online: https://ec.europa. eu/eurostat/statistics-explained/index.php?title=How_do_women_and_men_use_their_time_-_statistics\&oldid=463738 \#Overview (accessed on 25 May 2021).

21. European Institute for Gender Equality Browse Gender Statistics I Gender Statistics Database I European Institute for Gender Equality. Available online: https:/ / eige.europa.eu/gender-statistics/dgs/data-talks/what-lies-behind-gender-pay-gap (accessed on 21 May 2021).

22. Hanson, S. Gender and mobility: New approaches for informing sustainability. Gend. Place Cult. 2010, 17, 5-23. [CrossRef]

23. United Nations Department of Economic and Social Affairs (UN DESA). World's Population Increasingly Urban with more than Half Living in Urban Areas. Available online: https://www.un.org/en/development/desa/news/population/worldurbanization-prospects-2014.html (accessed on 21 May 2021).

24. Final Report Summary-LIVINGRAIL (Living in a Sustainable World Focused on Electrified Rail) | Report Summary | LIVINGRAIL | FP7 | CORDIS | European Commission. Available online: https://cordis.europa.eu/project/id/314036 /reporting/de (accessed on 21 May 2021).

25. Doll, C.; Mejia-Dorantes, L.; Dönitz, E. Applying visioning, roadmapping and simulation techniques for planning the european railway sector-results from the livingrail study. In Proceedings of the Transportation Research Board Annual 95th Meeting, Washington, DC, USA, 10-14 January 2016.

26. European Commission Transport Emissions. Climate Action; European Commission: Brussels, Belgium, 2014.

27. Faulin, J.; Grasman, S.E.; Juan, A.A.; Hirsch, P. Sustainable Transportation and Smart Logistics: Decision-Making Models and Solutions; Elsevier: Amsterdam, The Netherlands, 2018; ISBN 9780128142431.

28. Paramati, S.R.; Roca, E. Does tourism drive house prices in the OECD economies? Evidence from augmented mean group estimator. Tour. Manag. 2019, 74, 392-395. [CrossRef]

29. Fahra, L.; OHCHR. The Human Right to Adequate Housing. Available online: https://www.ohchr.org/EN/Issues/Housing/ Pages / AboutHRandHousing.aspx (accessed on 21 May 2021).

30. Lerondeau, M. Le Développement du Télétravail Prépare-t-il un Exode Urbain ? Available online: https://www. lafabriquedelacite.com/publications/le-developpement-du-teletravail-prepare-t-il-un-exode-urbain/ (accessed on 25 May 2021).

31. El éxodo al Revés: De la Ciudad al Campo I La Estela de la Pandemia. Available online: https:/ / elpais.com/masterdeperiodismo/ la-estela-de-la-pandemia /2020-08-02/el-exodo-al-reves-de-la-ciudad-al-campo.html?event_log=oklogin\&prod=REGINCOG\& $\mathrm{o}=$ incognito (accessed on 25 May 2021). 
32. Marsch, S. Escape to the Country: How Covid is Driving an Exodus from Britain's Cities I Coronavirus. Available online: https: //www.theguardian.com/world/2020/sep/26/escape-country-covid-exodus-britain-cities-pandemic-urban-green-space (accessed on 25 May 2021).

33. Scholz, K.-A. Are Berlin Residents Packing up and Leaving the City to Flee the Coronavirus? Available online: https://www.dw. com/en/berlin-coronavirus/a-54471392 (accessed on 25 May 2021).

34. Ahrendt, D.; Cabrita, J.; Clerice, E.; Hurley, J.; Leoncikas, T.; Mascherini, M.; Riso, S.; Sándor, E. Living, Working and COVID-19 I Eurofound. Available online: https://www.eurofound.europa.eu/publications/report/2020/living-working-and-covid-19 (accessed on 28 May 2021).

35. European Institute for Gender Equality. Available online: https:/ / eige.europa.eu/ (accessed on 21 May 2021).

36. Essential Workers I EIGE. Available online: https://eige.europa.eu/covid-19-and-gender-equality/essential-workers (accessed on 22 May 2021).

37. Madgavkar, A.; White, O.; Krishnan, M.; Mahajan, D.; Azcue, X. COVID-19 and Gender Equality: Countering the Regressive Effects; McKinsey Global Institute: New York, NY, USA, 2020.

38. Territori-Ärea Metropolitana de Barcelona. Available online: https://www.amb.cat/s/web/territori/territori.html (accessed on 21 May 2021).

39. Annual Indicators. Average Expenditure by Households. Base. 2017. Available online: https://www.idescat.cat/indicadors/ ?id=anuals\&n=10423\&lang=en\&t=201700 (accessed on 25 May 2021).

40. IDESCAT Extended results on commuting. Available online: https:/ $/$ www.idescat.cat $/ \mathrm{mobilitat} / \mathrm{?}=1 \&$ lang=en\&t=2001 (accessed on 27 May 2021).

41. Base Municipal. Institut Cartogràfic i Geològic de Catalunya. Available online: https://www.icgc.cat/ca/Descarregues/ Cartografia-vectorial/Base-municipal (accessed on 25 May 2021).

42. Perez, N.; Argomedo, D.A. La Mobilitat Quotidiana des d'una Perspectiva de Gènere-IERMB. Available online: https:/ / iermb. uab.cat/ca/estudi/la-mobilitat-quotidiana-des-duna-perspectiva-de-genere/ (accessed on 21 May 2021).

43. Marquet, O.; Miralles-Guasch, C. Walking short distances. The socioeconomic drivers for the use of proximity in everyday mobility in Barcelona. Transp. Res. Part A Policy Pract. 2014, 70, 210-222. [CrossRef]

44. Oficina Municipal de Datos I Barcelona Ciudad Digital. Available online: https://ajuntament.barcelona.cat/digital/es/ transformacion-digital/ city-data-commons/oficina-municipal-de-datos (accessed on 28 May 2021).

45. Instituto de la Mujer y Para la Igualdad de Oportunidades-Noticias y Novedades. Available online: https://www.inmujeres.gob. es/actualidad/noticias/2020/Mayo/InformeCOVID19.htm (accessed on 22 May 2021).

46. Statistical Institute of Catalonia. Segregation and quality of work indicators. In Gender Equality Index; Statistical Institute of Catalonia: Barcelona, Spain, 2018.

47. Productos y Servicios/Publicaciones/Colección Cifras INE. Available online: https://www.ine.es/ss/Satellite?L=es_ ES\&c=INECifrasINE_C\&cid=1259952649680\&p=1254735116567\&pagename=ProductosYServicios\%2FINECifrasINE_C\% 2FPYSDetalleCifrasINE (accessed on 21 May 2021).

48. How Usual Is It to Work from Home?-Products Eurostat News-Eurostat. Available online: https:/ / ec.europa.eu/eurostat/web/ products-eurostat-news/- /ddn-20200206-1 (accessed on 22 May 2021).

49. Pérez, G.R. La Pandemia Impulsa el Teletrabajo en España: Casi Tres Millones de Empleados a Distancia; El Pais: Madrid, Spain, 2021.

50. Checa, J.; Martín, J.; López, J.; Nello, O. Those who cannot stay at home: Urban mobility and social vulnerability in Barcelona during the COVID-19 pandemic. Bol. Asoc. Geogr. Esp. 2020. [CrossRef]

51. Sharifi, A.; Khavarian-Garmsir, A.R. The COVID-19 pandemic: Impacts on cities and major lessons for urban planning, design, and management. Sci. Total Environ. 2020, 749, 142391. [CrossRef] [PubMed]

52. Cómo se Mueve Alemania: Datos Móviles Para Mejorar Planes de Transporte. Available online: https://empresas.blogthinkbig. $\mathrm{com} /$ planes-movilidad-alemania / (accessed on 22 May 2021).

53. EMEF Daily Mobility Data in Metropolitan Area of Barcelona (Enquesta de Mobilitat en Dia Feiner-EMEF). Available online: https:/ / www.amtu.cat/enquestes-de-mobilitat-interurbana/1746-emef-2015 (accessed on 11 May 2021).

54. Montero, L.; Ros-Roca, X.; Herranz, R.; Barceló, J. Fusing mobile phone data with other data sources to generate input OD matrices for transport models. Transp. Res. Procedia 2019, 37, 417-424. [CrossRef]

55. PTV AG VISUM 2020. Available online: https://www.ptvgroup.com/fileadmin/user_upload/Products/PTV_Visum/ Documents/Release-Highlights/Overview_Visum2020.pdf (accessed on 22 May 2021).

56. R: The R Project for Statistical Computing. Available online: https://www.r-project.org/ (accessed on 22 May 2021).

57. RStudio. Open Source \& Professional Software for Data Science Teams—RStudio. Available online: https://www.rstudio.com/ (accessed on 22 May 2021).

58. CIVITAS Policy Note: Gender Equality and Mobility: Mind the Gap! | CIVITAS. Available online: http://civitas.eu/content/ civitas-policy-note-gender-equality-and-mobility-mind-gap (accessed on 28 May 2021).

59. Idescat. Survey on Living Conditions. Renda Mitjana Neta Anual per Unitat de Consum Després de Pensions Però Abans D'altres Transferències Socials per Edat. Catalunya. Available online: https://idescat.cat/pub/?id=ecv\&n=9349\&lang=en (accessed on 22 May 2021).

60. Lee, J.N.; Mahmud, M.; Morduch, J.; Ravindran, S.; Shonchoy, A.S. Migration, externalities, and the diffusion of COVID-19 in South Asia旋. J. Public Econ. 2021, 193. [CrossRef] 
61. Barcelona Analitza el Moviment Migratori en Temps de Pandèmia: Servei de Premsa. Available online: https:/ /ajuntament.barcelona. cat/premsa/2021/02/27/barcelona-analitza-el-moviment-migratori-en-temps-de-pandemia/ (accessed on 28 May 2021). 